\title{
MICROPROPAGATION, CONSERVATION, MOLECULAR AND BIOCHEMICAL STUDIES ON CAPPARIS SPINOSA VAR. DESERTI, A WILD ENDANGERED PLANT IN EGYPTIAN FLORA
}

Reda E. Abo El-Fadl ${ }^{1}$, Manal E.A.E. Ahmed ${ }^{1}$, Tamer M. Abd Elaziem ${ }^{1}$ Hamdy Ibrahim ${ }^{2}$, Omran Ghaly ${ }^{3,4}$, Mohamed Ewas ${ }^{5^{*}}$ and Mai A. Allam ${ }^{4.6}$

${ }^{1}$ Tissue Culture Unit, Department of Genetic Resources, Desert Research Center (DRC), Cairo, Egypt

${ }^{2}$ Biochemistry Unit, Department of Genetic Resources, Desert Research Center (DRC), Cairo, Egypt

${ }^{3}$ The Herbarium, Desert Research Center (DRC), Cairo, Egypt

${ }^{4}$ Regional Development Centers (RDC), Academy of Scientific Research and Technology (ASRT)

${ }^{5}$ Genetic and Cytology Unit, Department of Genetic Resources, Desert Research Center, Cairo, Egypt

${ }^{6}$ Center of Excellence for Advanced Sciences, Plant Biotechnology Department, National Research Center (NRC), Giza, Egypt

*E-mail: mohamed_ewas82@yahoo.com,omran_ghaly@yahoo.com apparis spinosa var. deserti Zohary (Family: considered as an excellent genetic source of flavonoids. It is a threatened species that is listed among the endangered and unutilized plant species. In an attempt to preserve C. spinosa from genetic erosion, micropropagation was employed as a useful way to mass propagate this plant due to the high population diversity and problems in traditional propagation methods. Furthermore, molecular and biochemical evaluation was carried out in C. spinosa callus under the influence of different chemical treatments. The best appropriate medium for proliferation of $C$. spinosa shoot tip explants was Murashige and Skoog (MS) medium supplemented with $2.0 \mathrm{mg} / 1$ 2iP. An efficient procedure for inducing high frequency direct shoot organogenesis from leaf explants in response to thidiazuron (TDZ) is reported. TDZ at $0.75 \mathrm{mg} / \mathrm{l}$ induced shoot organogenesis. The effect of different concentrations of two elicitors; salicylic acid (SA), methyl jasmonate (MeJA) and the precursor phenylalanine (Phe) on quercetin and rutin biosynthesis was examined. Metabolic results were confirmed by elevated transcript level of quercetin and rutin biosynthetic genes, 4-coumaroyl CoA ligase and flavonol-3-Oglucoside L-rhamnosyltransferase in $C$. spinosa callus. This study provides useful data regarding the vital role of plant growth regulators in conservation and micropropagation of C. spinosa var. deserti. Moreover, these results suggest that quercetin and rutin content in $C$. 
spinosa can be enhanced to a significant extent by SA, MeJA, and Phe treatments and the gene expression patterns of qurecetin and rutin biosynthesis-related genes are regulated by these elicitors.

Keywords: Capparis spinosa var. deserti, micropropagation, flavonoids, gene expression, 4-coumaroyl CoA ligase, flavonol-3-Oglucoside L-rhamnosyltransferase

\section{INTRODUCTION}

In the present context of unparalleled biodiversity loss (Eizaguirre and Baltazar-Soares, 2014 and IPBES, 2019), the molecular conservation of natural populations of plants is a vital goal for maintaining genetic diversity. These plants have a current or potential economic value either in themselves or as donor of genes. It is necessary therefore to set priority for what should be conserved. The first priority is for rare and endangered species. Among these priority plants, is caper (Capparis spinosa L. Family: Capparidaceae), which is a threatened species and it is listed among the endangered and unutilized plant species (NUS) as reported by Padulosi et al. (2002). Fortunately, this plant is well suited to the harsh Mediterranean summer climate (Levizou et al., 2004). In Egypt's flora, C. spinosa var. deserti Zohary, is classified as an endangered confined shrub to north of Siwa Oasis (Boulos, 2009). This plant is a part of the Egyptian plant diversity and is economically important. It is considered as a gene pool for its tolerance to the severe environmental conditions particularly drought stress where it grows naturally. Since the seed germination of this species is slow, so it is difficult to propagate naturally (Ben Salem et al., 2001; Yildirim and Bayram, 2001; Soyler and Khawar, 2007). Moreover, the rooting rate is very low in case of propagation by cuttings (Ben Salem et al., 2001 and Bhargava et al., 2006). Moreover, the slow growth is also a barrier, because apical and axillary buds become dormant during specific time periods (Sharma, 2014). The conventional method of propagation through seed is not preferred for multiplication of caper plant due to the low germination percentage probably, because its seed coat contains inhibitors (Ölmez et al., 2004). On the other side, C. spinosa has not been propagated through vegetative cuttings due to the low rooting percentage $(55 \%)$ with low success degree $(30 \%)$, as reported by Inocencio et al. (2002).

There is an urgent need to play a vital role towards the preservation of $C$. spinosa from gradual disappearance and extinction from their natural habitat in Southern Sinai. For our knowledge, results of vegetative propagation by stem cuttings appears to be strongly dependent on the type of propagation material as affected by the environment (Barbera and Di Lorenzo, 1984 ) and is therefore considered unsuitable for rapid clonal propagation or crop establishment (Ramezani-Gask et al., 2008 and Gruère et al., 2019). Tissue culture technique is one of the effective means of preserving plant

Egyptian J. Desert Res., 71, No. 2, 209-243 (2021) 
genetic resources. On the other hand, micropropagation is considered an interesting alternative for rapidly obtaining genetic homogenous and uniform plant material, suitable for more specialized plantings. It must be taken in right consideration, the possible somaclonal variations which are often observed in micropropagated plants, probably deriving from the massive use of hormones in the production cycle (Hare et al., 2016).

There is misuse of caper as a result of dietary habits, local culinary customs and the lack of home market for its products. Caper also is a medicinal plant that can be used in folk medicine and pharmaceutical industry (Abou Hadid et al., 2004). Capers are said to reduce flatulence and have antirheumatic properties, uses for arteriosclerosis, as diuretics, kidney disinfectants and vermifuges. Moreover, infusions and decoctions from caper root bark have been traditionally used for dropsy, anemia, arthritis and gout.

Capers contain considerable amounts of the antioxidant bioflavonoids (Soyler and Khawar, 2007). Flavonoids can be defined as phytochemical compounds with potential applications in medicinal chemistry (Feliciano et al., 2015 and Shan et al., 2017). The importance of these flavonoids is due to their various medicinal benefits to the human body, including anti-inflammatory, antiviral, antioxidant and anti-cancer properties (Ullah et al., 2020). These compounds are classified depending on their chemical structure into three major types including, flavonoids or bioflavonoids, isoflavonoids and neoflavonoids (De-Souza et al., 2021). Some of the best-known flavonoids are rutin and quercetin due to their medicinal benefits (Panche et al., 2016). Biosynthesis of secondary metabolites is often induced via chemical elicitors through upregulating their biosynthetic pathways genes (Giri and Zaheer, 2016). Previous elicitation studies reported the role of several chemical stimulants including salicylic acid (SA), methyl jasmonate (MeJA) and phenylalanine (Phe) to activate secondary metabolites production in different plants (Qian et al., 2004; Jiao et al., 2016 and Kianersi et al., 2020).

At molecular level, several genes play a vital role in plant secondary metabolites biosynthesis and transcription regulation within the biosynthetic pathway of flavonoids (Ewas et al., 2016; 2017 and Jan et al., 2021). Among these genes, 4-coumaroyl CoA ligase (4CL) and flavonol-3-O-glucoside Lrhamnosyltransferase (RT) have been reported to be directly implicated in the biosynthesis of various flavonoids in several medicinal plants, especially capers (Kianersi et al., 2020). It can be emphasized that 4CL and RT play a key role in a signal transduction pathway in response to different chemical elicitors and can regulate the biosynthesis of flavonoid compounds in plants (Giri and Zaheer, 2016 and Kianersi et al., 2020).

Nowadays, with increasing global demand for flower buds, cultivation of caper crop plays a vital role in the rural economy and village society (Chedraoui et al., 2017). The expansion of caper production faces many problems, including the great variability of population due to cross 
pollination behaviors that results in high degree of heterozygosity within progenies (Musallam et al., 2011). In order to maximize caper products utilization and for better natural exploitation as well as to prevent the genetic erosion of native population, in vitro culture methods have been experienced to overcome these problems and to improve caper mass clonal propagation production. Many previous studies reported that the combination of basic media composition and growth hormones intake should indeed be the first consideration in optimal growth and secondary metabolites accumulation (Hegazi et al., 2011; Musallam et al., 2011; Carra et al., 2012 and Goda et al., 2017), but the use of elicitors and precursors as adjunct to these two basics have been used with success in this work. This enhancement was performed by using the elicitors, SA and MeJA along with the precursor Phe, that provided significant increase in the flavonoids content quercetin and rutin more than flavonoids content estimated in wild plants. Also, genetic fidelity of micropropagated plants was confirmed through RAPD analysis and a stable chemical profile as estimated by HPLC analysis.

The current study aims to develop a stable and effective protocol for the clonal propagation of selected accessions of caper plants. This investigation also inclusive addressing the drawbacks of previous protocols, including the extreme heterogeneity, genotype and random response, which restrict the applicability of these protocols. This literature provides a good understanding of the optimal combination of influencing factors such as propagation methods, growth regulators sort and concentration, rooting media, length and duration individually or in combination. This work paves the way for a better understanding of the molecular mechanism of the genes involved in the biosynthesis pathway of different flavonoids in response to treatment with various chemical elicitors in $C$. spinose var. deserti.

\section{MATERIALS AND METHODS}

\section{Plant Material and Explants Preparation}

C. spinosa var. deserti explants were collected from Siwa Oasis, Marsa Matrouh governorate (North Coast), Egypt. Shoots with active growing terminal buds were selected, moistened, and wrapped. Explants were washed for 2-3 $\mathrm{h}$ under running tap water.

\section{Sterilization of Explants}

Surface sterilization was performed in the Laminar Air Flow Hood under full aseptic conditions to prevent explant contamination with bacteria or fungi after culturing in the medium. The explants were washed in soap and then rinsed for $1 \mathrm{~h}$ under running tap water. Surface disinfection of explants was performed using $70 \%$ ethanol for 1 min, followed by $25 \%(\mathrm{v} / \mathrm{v})$ Clorox (containing $5.25 \% \mathrm{NaOCl}$ ) for $5 \mathrm{~min}$, and then washed three times with sterile distilled water to eliminate Clorox residues. For $1 \mathrm{~min}$, mercuric chloride at 
$0.1 \%(\mathrm{w} / \mathrm{v})$ was utilized. Then, it was washed three times with sterile distilled water.

\section{Culture Conditions and Basic Nutrient Medium}

Sterilized shoots were dissected to stem node parts $(1.5-2 \mathrm{~cm}$ long) and shoot tips (0.5-1 cm long) and planted vertically on Murashige and Skoog (MS) solid basal medium (Murashige and Skoog, 1962). Sucrose (30 g/l) was added to MS medium. Benzyl adenine (BA), kinetin (Kin) 2isopentenyladenine (2iP), gibberellic acid $\left(\mathrm{GA}_{3}\right), \beta$-naphthalene acetic acid (NAA), indole-3-butyric acid (IBA) and 2,4- dichlorophenoxy acetic acid $(2,4-D)$ were used separately or in combination at various concentrations. Before using $2.7 \mathrm{~g} / \mathrm{l}$ phytagel, the media were adjusted to a $\mathrm{pH}$ of 5.7- 5.8. The media were dispensed into $40 \mathrm{ml}$ volumes in large jars. Jars were then sealed with polypropylene caps and autoclaved at $121^{\circ} \mathrm{C}$ for $20 \mathrm{~min}$ at a pressure of $1.12 \mathrm{~kg} / \mathrm{cm}^{2}$, before being allowed to $\mathrm{cool}\left(\mathrm{GA}_{3}\right.$ was sterilized by filtration by $0.22 \mu \mathrm{m}$ filter). In the Laminar Air Flow Hood, sterilized explants were cultured on prepared media under full aseptic conditions. Tissue culture jars were then put in an air-conditioned incubation room at $25 \pm 2{ }^{\circ} \mathrm{C}$ for $16 \mathrm{~h}$ photoperiod with light intensity of 3000 lux given by cool white light fluorescent tubes.

\section{Effect of BA with NAA on Initiation of Shoots}

Establishing of in vitro culture for stem node sections was carried out on MS medium supplemented with $0.0,0.5,1.0,2.0$ and $3.0 \mathrm{mg} / 1 \mathrm{BA}$ in combination with $0.0,0.1$ and $0.2 \mathrm{mg} / 1 \mathrm{NAA}$, for activation of shoot buds. Percentage of survived explants, growth induction percentage (\%) and mean number of axillary shoots/explant were recorded after six weeks of culture.

\section{Impact of Different Cytokinins on in Vitro Growth and Development}

The shoots were transferred to the multiplication stage after the initiation stage to MS medium supplemented with different concentrations of $\mathrm{BA}$, Kin and $2 \mathrm{iP}$ at $0.0,0.5,1.0,2.0$ and $3.0 \mathrm{mg} / \mathrm{l}$, respectively, for shoots multiplication. The explants were subcultured in glass jars on the optimum medium formula to provide stock materials for further experiments. After six weeks, the mean number and length $(\mathrm{cm})$ of axillary shoots/explant and hyperhydricity degree were recorded.

\section{Impact of TDZ and Zeatin on Direct Organogenesis}

The purpose of this experiment was to examine how different concentrations of TDZ and zeatin $(0.0,0.25,0.5,0.75,1.0$ and $1.5 \mathrm{mg} / \mathrm{l})$ impacted on in vitro shoots produced from young leaves (fully expanded). The average number and length of adventitious buds/explant, organogenesis percentage and hyperhydricity degree were determined after 12 weeks. 


\section{Effect of $\mathrm{GA}_{3}$ With or Without $2 \mathrm{iP}$ on the Elongation of in Vitro Proliferated Shoots}

To enhance the elongation of the in vitro proliferated shoots, an elongation experiment was carried out using MS salts and vitamins supplemented with different concentrations of $\mathrm{GA}_{3}(0.0,1.0,2.0,3.0$ and 4.0 $\mathrm{mg} / \mathrm{l}$ ) with or without $0.5 \mathrm{mg} / \mathrm{l} 2 \mathrm{iP}$. After eight weeks post-incubation, the average length of axillary shoots $(\mathrm{cm})$ was measured.

\section{Effect of Auxins; IBA and NAA, on the Rooting of Shoots}

In addition to the control (free from plant growth regulators), elongated shoots were tested for rooting on root induction MS medium containing $1 \mathrm{~g} / 1$ activated charcoal (AC), $30 \mathrm{~g} / 1$ sucrose, and $2.7 \mathrm{~g} / 1$ phytagel, as well as different auxin treatments; IBA, NAA, or both $(0.0,1.0,1.5$ and 2.0 $\mathrm{mg} / \mathrm{l})$. After eight weeks of culture, the rooting percentage (\%), mean number of roots/explant, mean length of roots, and shoot height $(\mathrm{cm})$ were determined.

\section{Acclimatization}

Rooted shoots (4-7 cm long) were washed from medium residues and fungicide-treated with topsin $(\mathrm{w} / \mathrm{v})$ solution, then hardened off in soilrite for two weeks before transplanting into pots filled with a sand-peat moss $(1: 1 \mathrm{v} / \mathrm{v})$ soil mixture. Transparent polyethylene bags were used to cover the pots, which were then placed in a greenhouse. After one week, the covers were progressively removed over the course of a month. The number of transplants that survived (\%) was registered.

\section{Induction and Maintenance of Callus}

In vitro derived leaves were cut into approximately $1 \mathrm{~cm}^{2}$ segments, and used as explants. They were cultured on the surface of MS medium supplemented with different concentrations and combinations of an auxin; 2,4-D and BA as a cytokinins. In addition to MS control medium (free from plant growth regulators). The media were supplied with $30 \mathrm{~g} / \mathrm{l}$ sucrose and the $\mathrm{pH}$ was adjusted to $5.7-5.8$ before gelling with $2.7 \mathrm{~g} / 1$ phytagel. Then were dispersed into $100 \mathrm{ml}$ glass jars, $30 \mathrm{ml}$ per each jar, and autoclaved at $121^{\circ} \mathrm{C}$ under a pressure of $1.2 \mathrm{~kg} / \mathrm{cm}^{2}$ for $15 \mathrm{~min}$. Cultures were incubated at $25 \pm 2^{\circ} \mathrm{C}$ in the total darkness till sufficient amount of calli were produced. Induced calli were transferred to fresh media of the same composition each four weeks. Ten replicates of each treatment were used, the percentage of callus formation and fresh weight of callus ( $\mathrm{g} / \mathrm{jar}$ ) were recorded after eight weeks of culture.

\section{Elicitation and Precurarization}

Chemical feeding: The produced calli were cultured on MS medium supplemented with $1.0 \mathrm{mg} / 1$ 2,4-D and $0.5 \mathrm{mg} / 1 \mathrm{BA}$, and augmented with three different concentrations of the two elicitors; SA (0, 25, 50 and $100 \mathrm{ppm})$ and $\operatorname{MeJA}(5,10$ and $20 \mathrm{ppm})$ and the precursor Phe at 25, 50 and $100 \mathrm{ppm}$ to elevate the amount of rutin and qurecetin. Cultures were incubated at the same conditions as described above. Each treatment consists of 10 replicates, and 
the percentages of callus formation and fresh weight of callus (g/jar) were recorded after four weeks of culture. Calli were dried by freezing to constant weights, and the dry weight of callus was taken as $\mathrm{g} / \mathrm{g}$ fresh weight.

\section{HPLC Analysis}

Materials: Rutin and quercetin were used as calibration standards. Rutin (94\%) was obtained from Sigma-Aldrich (India) and quercetin (99\%) was obtained from S.D Fine-Chem Ltd. All reagents and solvents were analytical and high-performance liquid chromatography (HPLC) grade. The powdered 30-days old calli material of C. spinosa var. deserti was collected.

Preparation of the extract: Calli extract was prepared by Soxhlet extraction of $100 \mathrm{~g}$ of powdered calli material using $70 \%$ ethanol at $80^{\circ} \mathrm{C}$ for about $5 \mathrm{~h}$ in successive batches. The first batch was extracted by adding 500 $\mathrm{ml}$ solvent for about $3 \mathrm{~h}$, and further two successive extractions were done by adding $300 \mathrm{ml} / \mathrm{batch}$ for $1 \mathrm{~h}$. After completion of extraction, the cooled liquid was concentrated by evaporating its liquid contents in rotary evaporator to remove the solvent residue to nil, with an approximate yield of $2 \%$. The extract powder was used for further experiments.

Instrumentation and chromatographic conditions: HPLC was performed on a Shimadzu LC-2030 C Prominence-i (Japan) system equipped with a quaternary low-pressure gradient solvent delivery LC-2030 pump with a high-pressure switching valves, online LC-2030 degasser unit, a highsensitivity LC-2030 ultraviolet (UV) detector, high-speed drive LC-2030 autosampler with a $100 \mu \mathrm{l}$ loop and it accommodates 216 samples at a time with direct access rack system and large-capacity column oven. The system controlled and data analyzed by laboratory solution system software. A gradient elution was carried out in Kinetex XB-C18 column $\left(100 \mathrm{~A}^{\circ}, 100 \mathrm{~mm}\right.$ $\times 4.6 \mathrm{~mm}, 2.6 \mu \mathrm{m}$ pore size). The mobile phase consists of two different solutions $0.5 \%$ acetic acid and acetonitrile which acted as solution $\mathrm{A}$ and solution B. All solutions were degassed and filtered through $0.45 \mu \mathrm{m}$ pore size filter. The gradient elution initial conditions were $18 \%$ of eluent $B$ with linear gradient to $18.5 \%$ from 0.01 to $7 \mathrm{~min}$, followed by linear gradient to $35 \%$ of eluent $\mathrm{B}$ at $9 \mathrm{~min}$ and this proportion being maintained for $2 \mathrm{~min}$. The mobile phase composition returned to the initial condition at $10 \mathrm{~min}$ and allowed to run for another $5 \mathrm{~min}$ before the injection of another sample. The total runtime of each sample is $15 \mathrm{~min}$. The flow rate was $1.0 \mathrm{ml} / \mathrm{min}$ and the sample injection volume was $5 \mu \mathrm{l}$. The column was maintained at $26^{\circ} \mathrm{C}$ throughout analysis and the UV detector was set at $356 \mathrm{~nm}$. Seventy percentage methanol used as a diluent for assay by HPLC analysis and the total LC runtime was 15 min. The instrument was calibrated and qualified before the analysis. Using these chromatographic conditions, it was possible to confirm the retention time (RT) of rutin and quercetin by injection of corresponding standards separately. 
Preparation of standard solution: Accurately weighed appropriate amounts of rutin and quercetin reference standards were dissolved in $70 \%$ methanol in a $25 \mathrm{ml}$ volumetric flask to obtain a stock solution. The concentration of rutin and quercetin in the solution was 220 , and $220 \mathrm{ppm}$, respectively. Working standard solutions were obtained by diluting the $2.0 \mathrm{ml}$ standard stock solution to $10 \mathrm{ml}$ volumetric flask and made up with $70 \%$ methanol to get a final concentration of 44,16 and $44 \mathrm{ppm}$ for rutin and quercetin.

Preparation of sample solution: The dried calli extract was prepared in $70 \%$ methanol to achieve the final concentration of $400 \mathrm{ppm}$. Before analysis, the solutions were filtered through $0.2 \mu \mathrm{m}$ nylon membrane filters.

Preparation of spiked sample solution: Three different volumes $(1$, 2 and $3 \mathrm{ml}$ ) of standard stock solution were added to the sample solution (400 ppm) separately. The standard stock solution was spiked into the samples to determine recovery. Before analysis, the solutions were filtered through 0.2 $\mu \mathrm{m}$ nylon membrane filters.

\section{Genetic Uniformity Assessment of Micropropagated Plants by RAPD Analysis}

Genomic DNA extraction: DNA was extracted from fresh leaves from the in vitro regenerated plantlets as well as control plants (mother plants) using a CTAB protocol (Zidani et al., 2005) and DNA concentration was determined by measuring OD260 at $260 \mathrm{~nm}$ wavelength using NanoDrop (ND-1000 spectrophotometer).

Random amplified polymeric DNA (RAPD): A set of fourteen random primers (Table S1) was used in the detection of polymorphism among the regenerated plantlets and control. RAPD-PCR was carried out in $25 \mu \mathrm{l}$ reaction volume containing $12.5 \mu \mathrm{L}$ Master Mix (Qiagen), $2 \mu \mathrm{L}$ primer $(20$ pmole), $2 \mu \mathrm{L}$ templates DNA of concentration $(20 \mathrm{ng} / \mu \mathrm{L})$ and $8.5 \mu \mathrm{L}$ water nuclease free.

Thermo cycling profile and determination of PCR products: PCR amplification was performed in a C1000-Thermo cycler (Master cycler gradient eppendorf) programmed to fulfill 40 cycles after an initial denaturation cycle for $5 \mathrm{~min}$ at $94^{\circ} \mathrm{C}$. Each cycle consisted of a denaturation step at $94^{\circ} \mathrm{C}$ for $30 \mathrm{~s}$, an annealing step at $40^{\circ} \mathrm{C}$ for $30 \mathrm{~s}$, and an elongation step at $72^{\circ} \mathrm{C}$ for $30 \mathrm{~s}$. A final extension step of was performed at $72^{\circ} \mathrm{C}$ for 7 min. The amplification products were resolved by electrophoresis in a $1.5 \%$ agarose gel containing ethidium bromide $(0.5 \mu \mathrm{g} / \mathrm{ml})$ in $1 \mathrm{X}$ TAE buffer $(45$ $\mathrm{mM}$ Tris borate, $1 \mathrm{mM}$ EDTA) at 95 volts. PCR products were visualized on UV light and photographed. Amplified products were visually investigated by presence or absence of the bands.

Capillary electrophoresis: DNA fragments (the in vitro regenerated plantlets as well as mother plants) were analyzed in the automatic multicapillary electrophoresis (QIAxcel-QIAGEN). Isolated DNA was placed 
in the instrument sample tray, $10 \mathrm{ml}$ of the DNA samples were automatically injected into the capillary channel and subjected to electrophoresis according to the protocol AM420 (method separation time: $420 \mathrm{~s}$ method injection time: $10 \mathrm{~s}$, method separation voltage: $5.0 \mathrm{kV}$ and method injection voltage: $5.0 \mathrm{kV}$ ) of the QIAxcel DNA Screening Kit.

\section{RNA Isolation, cDNA-Synthesis and q-RT-PCR Data Analysis}

Total RNA was extracted from both frozen plant and calli samples with Trizol reagent (Invitrogen) and the first-strand cDNA were synthesized using $3 \mu \mathrm{g}$ of RNA and $200 \mathrm{U}$ of M-MLV reverse transcriptase (Invitrogen) according to the manufacturer's protocol. RT-PCR was carried out to amplify a $400 \mathrm{bp}$ fragment of $4 C L$ and RT with 31 cycles using the first-strand cDNA as a template. In addition, actin was amplified with 24 cycles as an internal control. Real-time PCR was performed on an optical 96-well plate in an AB StepOnePlus PCR system (Applied Biosystems) by using SYBR Premix reagent F-415 (Thermo Scientific). Relative gene expression was calculated using a relative quantification method (Livak and Schmittgen, 2001). All primers used in this analysis are listed in table (S2).

\section{The Free Radical Scavenging Capacity of DPPH}

DPPH (1,1-diphenyl-2-picrylhydrazyl) free radical scavenging capacity of the calli extracts was evaluated spectrophotometrically by a slightly modified method of Brand-Williams, Cuvelier, and Berset (Brand et al., 1995) as described by Dulf et al. (2015). Briefly, methanolic extract/standard solution $(40 \mu \mathrm{L})$ was mixed with $200 \mu \mathrm{L}$ of DPPH solution $(0.02 \mathrm{mg} / \mathrm{ml})$ and incubate for $15 \mathrm{~min}$ at room temperature and then the absorbance was measured at $517 \mathrm{~nm}$ using a multi-mode plate reader (BioTek, Winuschi, VT, USA). The results were expressed as micromol Trolox equivalents ( $\mu \mathrm{mol} \mathrm{TE}$ ) $/ 100 \mathrm{~g}$ sample (DW). Scavenging activity was calculated as follow:

Radical-scavenging (DPPH) activity $(\%)=\left[\left({ }^{A}\right.\right.$ control- $-{ }^{A}$ sample $) /{ }^{A}$ control $] \times$ 100

Where ${ }^{A}$ is the absorbance at $515 \mathrm{~nm}$.

\section{Determination of the Oxidative Stress Biomarker Malondialdehyde}

The standard protocol of Madhava Rao and Sresty (2000) was used to measure malondialdehyde (MDA) dependent content and to determine lipid peroxidation. Fresh leaf tissues were ground in $0.1 \%$ trichloroacetic acid (TCA) and centrifuged at 10,000 $\mathrm{g}$ for $5 \mathrm{~min}$. Then, $4 \mathrm{ml}$ of thiobarbituric acid (TBA) (prepared in 20\% TBA) was added to $1 \mathrm{ml}$ of supernatant and boiled at $100^{\circ} \mathrm{C}$ for $30 \mathrm{~min}$. The reaction mixture was terminated on an ice bath, followed by centrifugation at $10,000 \mathrm{~g}$ for $10 \mathrm{~min}$. The intensity of color formation was read at 530 and $600 \mathrm{~nm}$ with a spectrophotometer (Beckman 640D, USA). 


\section{Data Analysis}

The experiments were subjected to completely randomized design. All data were represented as mean \pm SD and processed in SPSS. Two-way ANOVA followed by Tukey's test was used to determine significant difference between groups. Statistical significance was set at $P \leq 0.05$.

\section{RESULTS AND DISCUSSION}

\section{Micropropagation of Capparis spinosa var. deserti}

\subsection{Establishment stage}

The results displayed significant differences in the establishment rate between the treatment sets (Table 1). The explants started to respond after 45 days of culturing on MS medium supplemented with different concentrations and combinations of BA and NAA. The medium containing different concentrations of BA and NAA caused the earlier blooming of buds without necrosis (Fig. 1). The highest average establishment percentage (85\%) occurred on $2 \mathrm{mg} / \mathrm{l}$ BA combined with $0.1 \mathrm{mg} / \mathrm{l} \mathrm{NAA}$. In this study, new plantlets were regenerated from lateral buds, which were more stable than plants raised from callus. The lowest establishment percentage (18\%) was observed in the growth regulators-free treatment. The major goal of the establishing stage is to have a large proportion of explants that are pathogenfree (Murashige, 1974). The success of this stage is influenced by explant selection, contaminant removal, and culture conditions, which include additives, light, temperature, and explant support selection (Hartmann and Kester, 1983).

Table (1). In vitro establishment of stem node sections of Capparis spinosa var. deserti cultured on MS medium supplemented with BA and NAA. Results were taken after 6 weeks of culture.

\begin{tabular}{ccccc}
\hline $\begin{array}{c}\text { Growth regulators } \\
\text { conc. (mg/l) }\end{array}$ & $\begin{array}{c}\text { Percentage of } \\
\text { survived explants } \\
\text { (\%) }\end{array}$ & $\begin{array}{c}\text { Percentage of } \\
\text { growth induction } \\
(\%)\end{array}$ & $\begin{array}{c}\text { Mean number } \\
\text { of axillary } \\
\text { shoots/ explant }\end{array}$ \\
\cline { 1 - 2 } BA & NAA & $18^{\mathrm{k}}$ & $1.00^{\mathrm{k}}$ & $0.10^{\mathrm{l}}$ \\
\hline 0.0 & 0.0 & $40^{\mathrm{g}}$ & $10.00^{\mathrm{j}}$ & $1.00^{\mathrm{k}}$ \\
0.5 & 0.0 & $48^{\mathrm{f}}$ & $50.00^{\mathrm{h}}$ & $1.30^{\mathrm{j}}$ \\
1.0 & 0.0 & $55^{\mathrm{c}}$ & $78.00^{\mathrm{a}}$ & $2.40^{\mathrm{d}}$ \\
2.0 & 0.0 & $50^{\mathrm{e}}$ & $61.00^{\mathrm{d}}$ & $2.00^{\mathrm{f}}$ \\
3.0 & 0.0 & $30^{\mathrm{i}}$ & $15.00^{\mathrm{i}}$ & $1.62^{\mathrm{i}}$ \\
0.5 & 0.1 & $51^{\mathrm{d}}$ & $53.00^{\mathrm{f}}$ & $2.70^{\mathrm{b}}$ \\
1.0 & 0.1 & $85^{\mathrm{a}}$ & $70.00^{\mathrm{b}}$ & $2.83^{\mathrm{a}}$ \\
2.0 & 0.1 & $68^{\mathrm{b}}$ & $65.00^{\mathrm{c}}$ & $2.26^{\mathrm{c}}$ \\
3.0 & 0.1 & $20^{\mathrm{j}}$ & $1.00^{\mathrm{k}}$ & $1.30^{\mathrm{j}}$ \\
0.5 & 0.2 & $35^{\mathrm{h}}$ & $52.33^{\mathrm{g}}$ & $1.90^{\mathrm{g}}$ \\
1.0 & 0.2 & $40^{\mathrm{g}}$ & $65.00^{\mathrm{c}}$ & $2.10^{\mathrm{e}}$ \\
2.0 & 0.2 & $40^{\mathrm{g}}$ & $60.00^{\mathrm{e}}$ & $1.80^{\mathrm{h}}$ \\
\hline 3.0 & 0.2 & & &
\end{tabular}




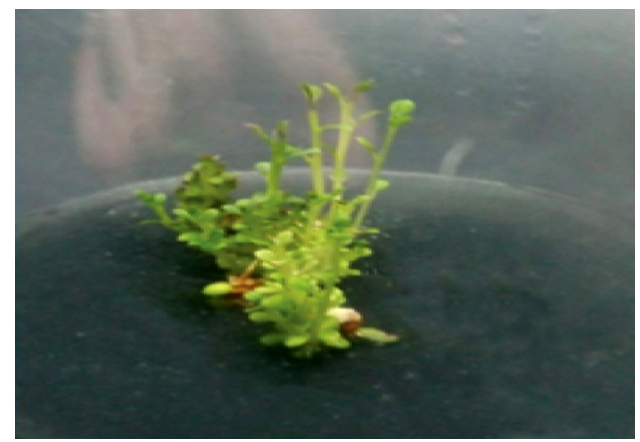

Fig. (1). Establishment of stem node sections of Capparis spinosa var. deserti on MS medium supplemented with $1 \mathrm{mg} / \mathrm{l} \mathrm{BA}$.

\subsection{Impact of different of cytokinins on the in vitro growth and development}

Multiplication is the fast growth of organs that might eventually result in the formation of a plant. This is accomplished by increasing axillary shoot initiation (Murashige, 1974). This step is done on a regular basis to achieve large-scale shoot multiplication for commercial purposes (Smith and Murashige, 1970). The success of micropropagation technique depends upon the use of growth regulators in the culture medium. Growth regulators regulate the growth and developmental processes. These are the key factors in initiating the process of regeneration in tissue culture. In most of in vitro studies, explants do not respond well on culture media without growth regulators. An interactive balance of auxins and cytokinins controlled the in vitro growth and differentiation response in plant tissues (Sharma, 2014). In the present study, the impact of three different kinds of cytokinins (BA, Kin and $2 \mathrm{iP}$ ) on C. spinosa var. deserti growth and development was carried out. The in vitro multiplication of shoots is shown in (Table 2 and Fig. 2).

The findings show the influence of different concentrations of BA, Kin, and 2iP, as well as the control medium without plant growth regulators, on C. spinosa var. deserti multiplication. 2iP produced more shoots than BA or Kin, MS medium supplemented with $2.0 \mathrm{mg} / 12 \mathrm{iP}$ gave 7 shoots/explant. In comparison to the other treatments, MS medium containing $0.5 \mathrm{mg} / 12 \mathrm{iP}$ produced the longest mean length of axillary shoots $(0.81 \mathrm{~cm})$. MS medium containing $2.0 \mathrm{mg} / 12 \mathrm{iP}$ was the most suitable medium for multiplication of shoot tip explants. This medium gave the highest percentage of survival $(100 \%)$ and mean number (7.0) of axillary shoots per explant with high hyperhydricity degree (3.2). In this respect, it is important to mention that the medium including formation and growth of adventitious shoots from explants should contain more cytokinin in relation to auxin (Murashige, 1974). Cytokinin such as BA enhances cell division and formation of adventitious buds and shoots (Torres, 1989). Also, Elmaghrabi et al. (2017) showed that multiple branches and leaves of $C$. spinosa were obtained on MS medium 
supplemented with $2.0 \mathrm{mg} 2 \mathrm{iP}, \mathrm{Kin}$ or zeatin. The positive effect of $2 \mathrm{iP}$ as a cytokinin in the enhancement of in vitro formed shoots agrees with the observations of Hassanein et al. (2008), who found that 2iP gave promising results in enhancing of axillary shoots of Capparis cartilaginea by using 0.5 or $1 \mathrm{mg} / \mathrm{L}$

Table (2). Effect of BA, Kin and 2iP on the proliferation of Capparis spinosa var. deserti axillary shoots.

\begin{tabular}{cccccc}
\hline $\begin{array}{c}\text { Growth regulators conc. } \\
\text { (mg/l) }\end{array}$ & $\begin{array}{c}\text { Mean number } \\
\text { of axillary } \\
\text { shoots/ explant }\end{array}$ & $\begin{array}{c}\text { Mean length of } \\
\text { axillary shoots } \\
\text { (cm) }\end{array}$ & $\begin{array}{c}\text { Hyperhydricity } \\
\text { degree }\end{array}$ \\
\hline BA & Kin & 2iP & \\
\hline 0.0 & 0.0 & 0.0 & $0.10^{\mathrm{k}}$ & $0.10^{\mathrm{j}}$ & $1.1^{1}$ \\
0.5 & 0.0 & 0.0 & $2.00^{\mathrm{i}}$ & $0.73^{\mathrm{h}}$ & $2.2^{\mathrm{g}}$ \\
1.0 & 0.0 & 0.0 & $3.00^{\mathrm{e}}$ & $0.70^{\mathrm{i}}$ & $2.8^{\mathrm{e}}$ \\
2.0 & 0.0 & 0.0 & $5.00^{\mathrm{c}}$ & $0.81^{\mathrm{a}}$ & $4.2^{\mathrm{b}}$ \\
3.0 & 0.0 & 0.0 & $6.00^{\mathrm{b}}$ & $0.79^{\mathrm{g}}$ & $4.9^{\mathrm{a}}$ \\
0.0 & 0.5 & 0.0 & $1.00^{\mathrm{j}}$ & $0.74^{\mathrm{g}}$ & $1.3^{\mathrm{k}}$ \\
0.0 & 1.0 & 0.0 & $2.00^{\mathrm{i}}$ & $0.78^{\mathrm{d}}$ & $1.5^{\mathrm{j}}$ \\
0.0 & 2.0 & 0.0 & $2.31^{\mathrm{g}}$ & $0.76^{\mathrm{f}}$ & $1.9^{\mathrm{i}}$ \\
0.0 & 3.0 & 0.0 & $2.10^{\mathrm{h}}$ & $0.77^{\mathrm{e}}$ & $2.1^{\mathrm{h}}$ \\
0.0 & 0.0 & 0.5 & $2.00^{\mathrm{i}}$ & $0.81^{\mathrm{a}}$ & $2.1^{\mathrm{h}}$ \\
0.0 & 0.0 & 1.0 & $2.80^{\mathrm{f}}$ & $0.80^{\mathrm{b}}$ & $2.5^{\mathrm{f}}$ \\
0.0 & 0.0 & 2.0 & $7.00^{\mathrm{a}}$ & $0.77^{\mathrm{e}}$ & $3.2^{\mathrm{c}}$ \\
0.0 & 0.0 & 3.0 & $4.00^{\mathrm{d}}$ & $0.74^{\mathrm{g}}$ & $3.1^{\mathrm{d}}$ \\
\hline
\end{tabular}

Fig. (2). Proliferation of shoots of Capparis spinosa var. deserti on MS medium supplemented with $2.0 \mathrm{mg} / 12 \mathrm{iP}$.

\subsection{Influence of TDZ and zeatin on direct organogenesis}

In vitro organogenesis of woody species plays an essential role in the improvement of forest products by providing saplings with high commercial value. An efficient and simple procedure for inducing high frequency direct shoot organogenesis in C. spinosa var. deserti from leaf explants in response to TDZ and zeatin is reported. The impact of the tested MS medium supplemented with various levels of TDZ and zeatin on the number of 
adventitious buds, hyperhydricity degree and regeneration frequency throughout the organogenesis process are shown in table (3) and fig. (3). Leaf explants were used to produce the shoots. Shoot regeneration began in the second week and lasted until the completion of the study (12 weeks). When it came to the quantity of adventitious buds, the influence of TDZ on the trait was significant, especially when MS culture medium was supplemented with $0.75 \mathrm{mg} / \mathrm{l}$, resulting in 14 adventitious shoots/explant. Likewise, the impact of zeatin on the given trait was significant, particularly when zeatin was added to MS culture medium at $0.75 \mathrm{mg} / \mathrm{l}$, which resulted in the highest mean value of the defined character ( 2.0 adventitious buds/explant).

Table (3). The effect of cytokinin concentration on the formation of adventitious shoots (direct organogenesis) from Capparis spinosa var. deserti leaf explants.

\begin{tabular}{|c|c|c|c|c|c|}
\hline \multicolumn{2}{|c|}{$\begin{array}{c}\text { Growth regulators } \\
\text { conc. }(\mathrm{mg} / \mathrm{l})\end{array}$} & \multirow{2}{*}{$\begin{array}{c}\text { Organogenesis } \\
\text { percentage } \\
(\%)\end{array}$} & \multirow{2}{*}{$\begin{array}{l}\text { Mean number } \\
\text { of adventitious } \\
\text { shoots/explant }\end{array}$} & \multirow{2}{*}{$\begin{array}{l}\text { Mean length of } \\
\text { axillary shoots } \\
\text { (cm) }\end{array}$} & \multirow[t]{2}{*}{$\begin{array}{c}\text { Hyperhydricity } \\
\text { degree }\end{array}$} \\
\hline TDZ & Zeatin & & & & \\
\hline 0.00 & 0.00 & $1^{\mathrm{g}}$ & $0.1^{\mathrm{h}}$ & $0.1^{\mathrm{g}}$ & $1.00^{\mathrm{h}}$ \\
\hline 0.25 & 0.00 & $30^{\mathrm{d}}$ & $6.0^{\mathrm{d}}$ & $2.8^{\mathrm{c}}$ & $1.10^{\mathrm{g}}$ \\
\hline 0.50 & 0.00 & $75^{\mathrm{b}}$ & $9.0^{\mathrm{c}}$ & $2.6^{\mathrm{d}}$ & $1.10^{\mathrm{g}}$ \\
\hline 0.75 & 0.00 & $80^{\mathrm{a}}$ & $14.0^{\mathrm{a}}$ & $2.0^{\mathrm{f}}$ & $1.10^{\mathrm{g}}$ \\
\hline 1.00 & 0.00 & $75^{\mathrm{b}}$ & $10.0^{\mathrm{b}}$ & $2.5^{\mathrm{e}}$ & $1.20^{\mathrm{e}}$ \\
\hline 1.50 & 0.00 & $70^{c}$ & $4.0^{\mathrm{e}}$ & $3.0^{\mathrm{a}}$ & $1.50^{\mathrm{d}}$ \\
\hline 0.00 & 0.25 & $1^{\mathrm{g}}$ & $0.1^{\mathrm{h}}$ & $0.1^{\mathrm{g}}$ & $1.13^{\mathrm{f}}$ \\
\hline 0.00 & 0.50 & $5^{\mathrm{f}}$ & $1.0^{\mathrm{g}}$ & $3.0^{\mathrm{a}}$ & $1.20^{\mathrm{e}}$ \\
\hline 0.00 & 0.75 & $9^{\mathrm{e}}$ & $2.0^{\mathrm{f}}$ & $2.9^{\mathrm{b}}$ & $1.60^{\mathrm{c}}$ \\
\hline 0.00 & 1.00 & $1^{\mathrm{g}}$ & $0.1^{\mathrm{h}}$ & $0.1^{\mathrm{g}}$ & $1.70^{\mathrm{b}}$ \\
\hline 0.00 & 1.50 & $1^{\mathrm{g}}$ & $0.1^{\mathrm{h}}$ & $0.1^{\mathrm{g}}$ & $1.80^{\mathrm{a}}$ \\
\hline \multicolumn{2}{|c|}{ L.S.D at $5 \%$} & & $0.5^{1}$ & 7.60 & 0.02 \\
\hline
\end{tabular}

Furthermore, TDZ showed a very highly significant $(P \leq 0.005)$ effect on the traits under study, especially when MS medium was augmented with TDZ at $0.75 \mathrm{mg} / \mathrm{l}$, which achieved the highest organogenesis percentage (80\%) compared to other treatments. In the case of hyperhydricity, it was observed in all of the treatments at varying degrees. The highest vitrification value was obtained using MS medium containing $1.50 \mathrm{mg} / \mathrm{l}$ zeatin (1.8). On the other hand, Hassan and Abdelkader (2015) showed that the highest significant number of axillary shoots/explant, axillary shoot length, number of leaves/shoot and main shoot length of $4.22,23.04$ and $4.77 \mathrm{~cm}$, respectively were recorded when nodal explants of caper were cultured on MS medium supplemented with $0.5 \mathrm{mg} / 1 \mathrm{BA}$ combined with $0.1 \mathrm{mg} / 1 \mathrm{NAA}$ during establishment stage. While in the multiplication stage, BA at $0.5 \mathrm{mg} / \mathrm{l}$ combined with $0.1 \mathrm{mg} / 1 \mathrm{NAA}$ and $1.0 \mathrm{mg} / 1$ diphenyelurea gave the highest values of axillary shoot length, number of leaves/shoot and main shoot length 
of $17.74,8.88$ and $11.66 \mathrm{~cm}$, respectively. Also, Mehrabani (2016) showed that the highest shoots proliferation of Capparis spinosa was obtained on MS medium supplemented with $3 \mathrm{mg} / 1$ cytokinin. More shoot multiplication was obtained at the same medium by subculturing shoot segments with 2-3 nodes every seven weeks (for two times).
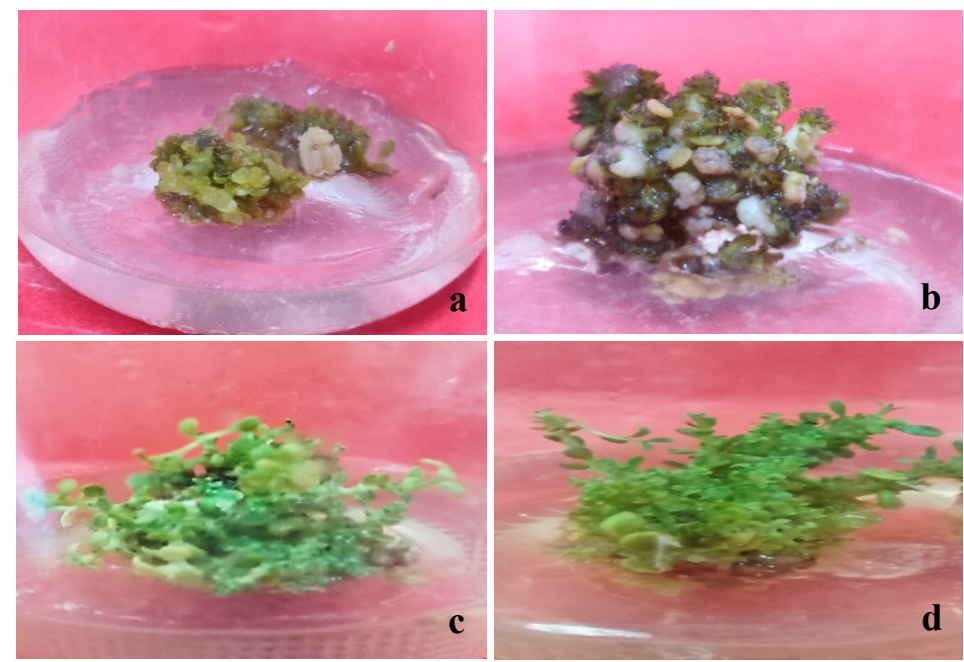

Fig. (3). Organogenesis process of Capparis spinosa var. deserti a. Swilling of leaf buds; $\mathbf{b}$. Organogenesis induction on MS medium containing $0.75 \mathrm{mg} / 1 \mathrm{TDZ}$; c. Development of organs after 6 weeks; d. Advanced shoot formation after the second subculture.

\subsection{Effect of $\mathrm{GA}_{3}$ with or without $2 \mathrm{iP}$ on the elongation of in vitro proliferated shoots}

The effect of various concentrations of $\mathrm{GA}_{3}$ and/or $2 \mathrm{iP}$ on the elongation of proliferated axillary shoots after several subcultures was investigated. Table 4 and fig. (4) show the effect of various concentrations of $\mathrm{GA}_{3}$ alone or in combination with $2 \mathrm{iP}$ on the elongation of $C$. spinosa var. deserti in vitro proliferated shoots. In comparison to the other tested media, MS medium containing $3 \mathrm{mg} / 1 \mathrm{GA}_{3}$ produced substantially the highest mean length of axillary shoots of approximately $4.2 \mathrm{~cm}$ (Fig. 4). The combination of $\mathrm{GA}_{3}$ and $2 \mathrm{iP}$ produced the least response, making this treatment unsuitable for promoting axillary shoot elongation. The medium containing $0.5 \mathrm{mg} / 12 \mathrm{iP}$ in addition to $3 \mathrm{mg} / \mathrm{l} \mathrm{GA} 3$ was superior in its effect on shoot elongation, indicating that $2 \mathrm{iP}$ showed improvement of axillary shoots elongation. This positive effect of $2 \mathrm{iP}$ as a cytokinin in enhancing the elongation of in vitro produced shoots is compatible with Hassanein et al. (2008) findings that 2iP gave encouraging results in enhancing the elongation of axillary shoots of Capparis cartilaginea using 0.5 or $1 \mathrm{mg} / 12 \mathrm{iP} . \mathrm{GA}_{3}$ is an effective growth regulator for seed germination as well shoot elongation. A number of workers

Egyptian J. Desert Res., 71, No. 2, 209-243 (2021) 
used $\mathrm{GA}_{3}$ in their culture media and found useful results (Kotnala et al., 2011 and Al-Safadi and Elias, 2011).

Table (4). Elongation of in vitro proliferated shoots of Capparis spinosa var. deserti cultured for 6 weeks on MS medium supplemented with different concentrations of $\mathrm{GA}_{3}$ and $2 \mathrm{iP}(0.5 \mathrm{mg} / \mathrm{l})$.

\begin{tabular}{|c|c|c|}
\hline \multicolumn{2}{|c|}{$\begin{array}{l}\text { Growth regulators conc. } \\
\qquad(\mathrm{mg} / \mathbf{l})\end{array}$} & \multirow[t]{2}{*}{$\begin{array}{l}\text { Mean length of axillary shoots } \\
\qquad(\mathrm{cm})\end{array}$} \\
\hline $\mathbf{G A}_{3}$ & $2 \mathrm{iP}$ & \\
\hline 1 & 0.0 & $2.1^{\mathrm{g}}$ \\
\hline 2 & 0.0 & $2.4^{\mathrm{d}}$ \\
\hline 3 & 0.0 & $4.2^{\mathrm{a}}$ \\
\hline 4 & 0.0 & $3.5^{\mathrm{b}}$ \\
\hline 1 & 0.5 & $1.8^{\mathrm{h}}$ \\
\hline 2 & 0.5 & $2.2^{\mathrm{f}}$ \\
\hline 3 & 0.5 & $2.7^{\mathrm{c}}$ \\
\hline 4 & 0.5 & $2.3^{\mathrm{e}}$ \\
\hline
\end{tabular}

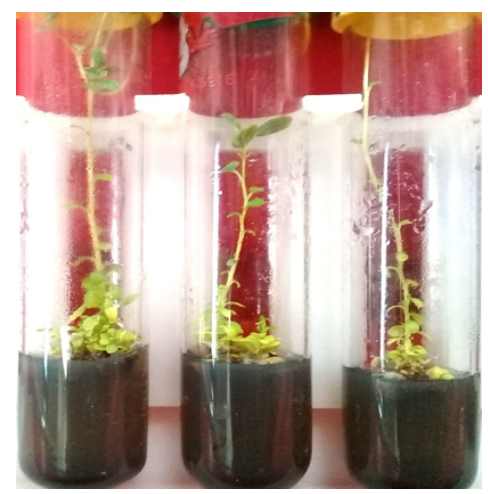

Fig. (4). Elongation of Capparis spinosa var. deserti shoots on MS medium containing $3 \mathrm{mg} / \mathrm{l} \mathrm{GA}_{3}$.

\subsection{Effect of auxins; IBA and NAA, on the rooting of shoots}

The aim of the rooting stage is to prepare the plantlets for transplantation and establishment outside of the culture vessel's artificial, closed atmosphere (Hartmann and Kester, 1983). The transition to conditions that favour shoot elongation and root initiation is the most significant change at this point. The rooting of shoot cuttings was done at this point. Rooting of shoot cuttings, hardening of plants to impart some moisture stress tolerance, and conversion of plants from heterotrophic to autotrophic states are all part of this level (Murashige, 1977). In this experiment, elongated shoots with a length of at least $3 \mathrm{~cm}$ were checked for rooting in vitro.

Sixty days post-incubation, the highest rooting percentage of (54.33\%) was obtained on MS medium supplemented with $1.5 \mathrm{mg} / 1 \mathrm{IBA}$ plus 
$1.0 \mathrm{mg} / \mathrm{l} \mathrm{NAA} \mathrm{(Table} 5$ and Fig. 5). In addition, the mean number and length of roots and shoot height were also superior on this medium; they reached 6.2, $2.3 \mathrm{~cm}$ and $5.3 \mathrm{~cm}$, respectively. Subsequently, explants treated with $2 \mathrm{mg} / 1$ of IBA plus $1.0 \mathrm{mg} / 1 \mathrm{NAA}$ achieved $50 \%$ rooting. On MS medium supplemented with 0.5 or $1.0 \mathrm{mg} / 1 \mathrm{IBA}$, however, the lowest significant rooting percentage was obtained. Since then, high IBA concentrations have promoted tissue lignification, resulting in a significant reduction in rooting capacity. Capparis spinosa was confronted with this problem (Ben Salem et al., 2001). There was no rooting response in the control MS medium, which was devoid of growth regulators. In vitro produced plantlets with welldeveloped roots were successfully acclimatized ex vitro in the greenhouse conditions. Transplants showed good growth and uniformity (Fig. 6).

Table (5). Effect of MS medium containing $1 \mathrm{~g} / 1 \mathrm{AC}$ and different treatments of auxins; IBA and NAA, on the rooting of Capparis spinosa var. deserti shoots.

\begin{tabular}{|c|c|c|c|c|c|}
\hline \multicolumn{2}{|c|}{$\begin{array}{c}\text { Auxin conc. } \\
(\mathrm{mg} / \mathrm{l})\end{array}$} & \multirow[t]{2}{*}{$\begin{array}{l}\text { Rooting } \\
\quad(\%)\end{array}$} & \multirow[t]{2}{*}{$\begin{array}{l}\text { Mean number of } \\
\text { roots/ explant }\end{array}$} & \multirow[t]{2}{*}{$\begin{array}{l}\text { Mean length } \\
\text { of roots }(\mathrm{cm})\end{array}$} & \multirow[t]{2}{*}{$\begin{array}{l}\text { Mean shoot } \\
\text { height }(\mathrm{cm})\end{array}$} \\
\hline IBA & NAA & & & & \\
\hline 0.0 & 0.0 & $0.10^{1}$ & $0.1^{1}$ & $0.20^{\mathrm{p}}$ & $2.5^{\mathrm{p}}$ \\
\hline 0.5 & 0.0 & $20.00^{\mathrm{j}}$ & $2.1^{\mathrm{k}}$ & $1.10^{\mathrm{h}}$ & $2.9^{\circ}$ \\
\hline 1.0 & 0.0 & $22.00^{\mathrm{i}}$ & $3.1^{\mathrm{j}}$ & $1.20^{\mathrm{g}}$ & $3.5^{\mathrm{k}}$ \\
\hline 1.5 & 0.0 & $25.00^{\mathrm{g}}$ & $4.1^{\mathrm{d}}$ & $1.40^{\mathrm{e}}$ & $4.1^{\mathrm{h}}$ \\
\hline 2.0 & 0.0 & $23.00^{\mathrm{h}}$ & $3.5^{\mathrm{g}}$ & $1.30^{\mathrm{f}}$ & $3.8^{\mathrm{i}}$ \\
\hline 0.0 & 0.5 & $20.00^{\mathrm{j}}$ & $3.2^{\mathrm{i}}$ & $0.72^{\mathrm{k}}$ & $3.1^{\mathrm{n}}$ \\
\hline 0.0 & 1.0 & $20.00^{\mathrm{j}}$ & $3.8^{\mathrm{e}}$ & $0.79^{j}$ & $3.4^{1}$ \\
\hline 0.0 & 1.5 & $28.00^{\mathrm{f}}$ & $4.2^{\mathrm{c}}$ & $0.81^{\mathrm{i}}$ & $3.6^{j}$ \\
\hline 0.0 & 2.0 & $25.00^{\mathrm{g}}$ & $4.1^{\mathrm{d}}$ & $0.79^{j}$ & $3.2^{\mathrm{m}}$ \\
\hline 0.5 & 0.5 & $15.00^{\mathrm{k}}$ & $3.2^{\mathrm{i}}$ & $0.61^{\circ}$ & $4.2^{\mathrm{g}}$ \\
\hline 1.0 & 0.5 & $15.00^{\mathrm{k}}$ & $3.4^{\mathrm{h}}$ & $0.63^{\mathrm{n}}$ & $4.5^{\mathrm{f}}$ \\
\hline 1.5 & 0.5 & $25.00^{\mathrm{g}}$ & $3.6^{\mathrm{f}}$ & $0.65^{1}$ & $4.7^{\mathrm{d}}$ \\
\hline 2.0 & 0.5 & $30.00^{\mathrm{e}}$ & $3.5^{\mathrm{g}}$ & $0.64^{\mathrm{m}}$ & $4.1^{\mathrm{h}}$ \\
\hline 0.5 & 1.0 & $37.00^{\mathrm{d}}$ & $4.1^{\mathrm{d}}$ & $1.70^{\mathrm{d}}$ & $4.6^{\mathrm{e}}$ \\
\hline 1.0 & 1.0 & $40.00^{c}$ & $4.8^{\mathrm{b}}$ & $1.90^{\mathrm{c}}$ & $4.9^{c}$ \\
\hline 1.5 & 1.0 & $54.33^{\mathrm{a}}$ & $6.2^{\mathrm{a}}$ & $2.30^{\mathrm{a}}$ & $5.3^{\mathrm{a}}$ \\
\hline 2.0 & 1.0 & $50.00^{\mathrm{b}}$ & $3.1^{\mathrm{j}}$ & $2.10^{\mathrm{b}}$ & $5.1^{\mathrm{b}}$ \\
\hline \multicolumn{2}{|c|}{ L.S.D at $5 \%$} & 0.46 & 0.46 & 3.93 & 5.14 \\
\hline
\end{tabular}

Egyptian J. Desert Res., 71, No. 2, 209-243 (2021) 

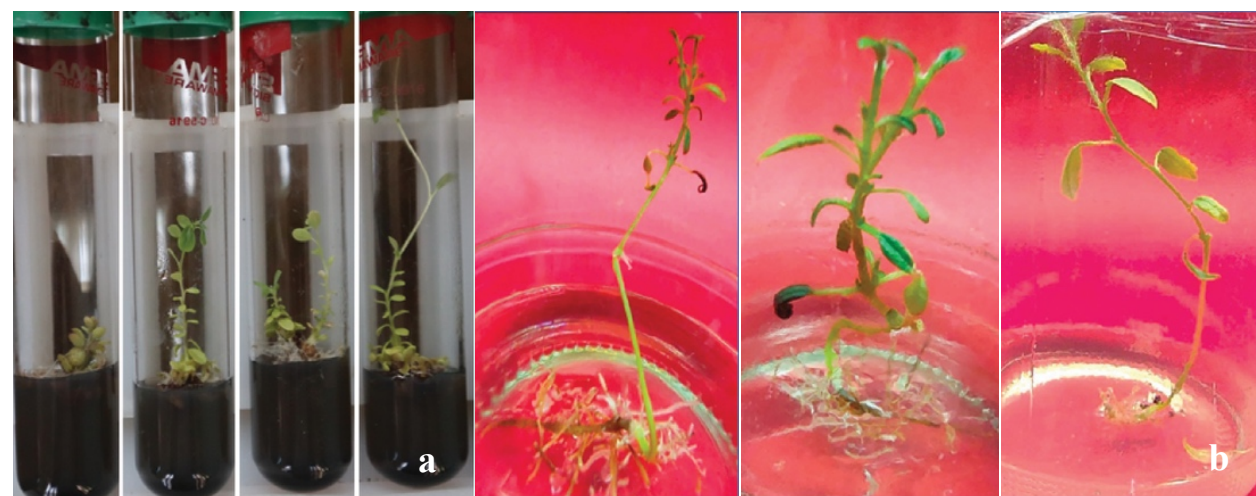

Fig. (5). Rooting of Capparis spinosa var. deserti on MS medium supplemented with $1.5 \mathrm{mg} / 1 \mathrm{IBA}$ plus $1.0 \mathrm{mg} / 1 \mathrm{NAA}$ after 60 days of incubation. a. Rooting initiation; b. Rooting development.
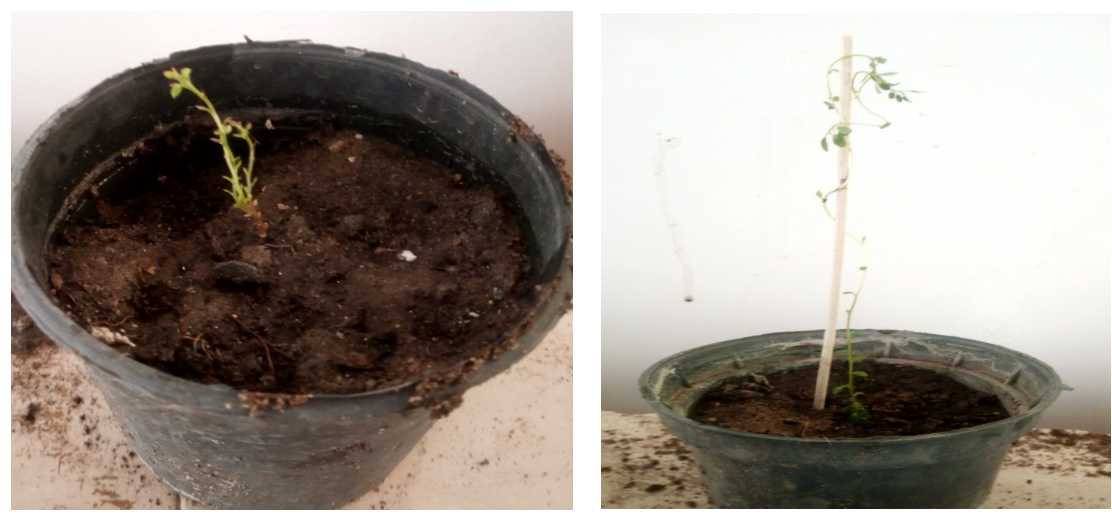

Fig. (6). Hardened in vitro derived plantlets of Capparis spinosa var. deserti.

A previous study on axillary buds of wild $C$. spinosa plants reported that the highest percentage of average number of rooted shoots $(56.7 \%)$ was obtained with $1.5 \mathrm{mg} / 1$ NAA (Attia et al., 2017). In another study, Capparis species, such as $C$. decidua, the best rooting result was achieved on a medium supplemented with IBA (1 mg/l) (Tyagi and Kothari, 1997), but in a subsequent work of the same authors (Tyagi et al., 2010), $1.0 \mathrm{mg} / 1 \mathrm{IBA}$ combined with $0.5 \mathrm{mg} / 1$ IAA was considered better, whereas Deora and Shekhawat (1995) found that $60-70 \%$ of the shoots rooted when pulse treated with $100 \mathrm{mg} / \mathrm{l}$ IBA. In another species (C. orientalis), closely related to $C$. spinosa, the highest rooting percentage $(60 \%)$ was obtained with $1 \mathrm{mg} / \mathrm{l}$ of both IBA and NAA (Hegazi et al., 2011) and, lastly, Carra et al. (2012), found that the rooting rate of the wild bushes $C$. orientalis was equally efficient in the media supplemented with $2 \mathrm{mg} / 1$ of IAA or IBA, or in growth regulatorfree rooting medium, whereas NAA at $2 \mathrm{mg} / \mathrm{l}$ was discarded due to the 
abundant callus formation on the induced roots. Also, Mehrabani (2016) showed that auxin type (IBA and NAA), levels $(0,1$ and $2 \mathrm{mg} / \mathrm{l})$ and medium strength $(1 / 2 \mathrm{MS}$ and MS) as well as cultivar (Varzegan and Miyaneh) of $C$. spinosa had profound effects on root number. The result showed that, with increasing auxins concentration, rooting percentage was increased. The greatest rooting response was acquired from MS medium supplemented with $2 \mathrm{mg} / \mathrm{l}$ of NAA. Finally, Kereša et al. (2019) showed that the rooting was equally efficient in the media supplemented with $2 \mathrm{mg} / 1$ of indole-3-acetic acid (IAA) or IBA or in growth regulator-free rooting medium. A prolonged time in the media increased the rooting efficiency, while the carry-over effect had no influence. The acclimatization rate reached $66 \%$. BA and its stable derivatives are suspected to inhibit rooting, whereas meta-topolin (mT), an aromatic natural cytokinin alternative to BA, and its derivatives do not inhibit in vitro root formation, and their breakdown is relatively fast. Nonetheless, they did not find any significant difference in the rooting efficiency between the microshoots previously proliferated in the two different cytokinins, BA, and $\mathrm{mT}$, probably due to the very low concentration of cytokinins used during the proliferation phase.

Micropropagated plants of $C$, spinosa var. deserti were conserved ex situ at the field gene bank of the Regional Center for Conservation and Maintenance of Endangered Plant Genetic Resources at El-Hammam city, Matrouh Governorate Egypt.

\subsection{Genetic uniformity assessment of micropropagated plants by RAPD analysis}

For genetic uniformity surveys, RAPD was performed to analyze the genetic stability of in vitro regenerated plants of a random selection manner as well as the mother plant using four random primers. Out of fourteen random primers, two primers succeeded to develop high amplification (Table S1 and Fig. 7). Fig. (7) shows the similar banding patterns between mother and random in vitro regenerated plants that puts an emphasis on that the clonal propagation was developed with low risk of somaclonal variation or any genetic aberration in regenerated plant. Genetic assessment of the in vitro regenerated plants by RAPD markers has been reported (Martins et al., 2004 and Venkatachalam et al., 2007). Bhowmik et al. (2009) reported genetic uniformity of in vitro micropropagated Mantisia spathulata using RAPD analysis. Also, all banding profiles from regenerated plants of Alpinia galanga L. were similar to the mother plant (Parida et al., 2011). 
a

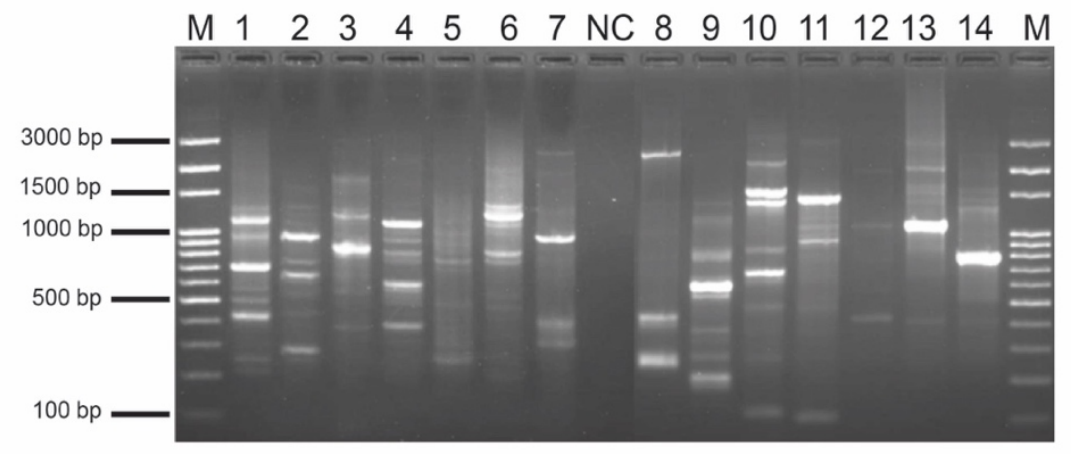

b

C
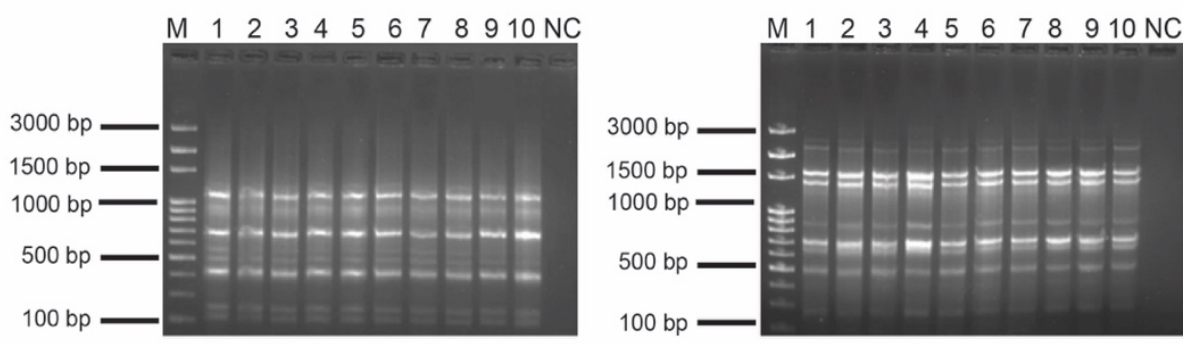

Fig. (7). Genetic fidelity assessment among micropropagated and mother plants of Capparis spinosa var. deserti using RAPD marker. a. Screening various primers for polymorphism. M: 100 bp ladder, 1: OPC-08, 2: OPC-10, 3: OPC-15, 4: OPD-20, 5: OPG-03, 6: OPD12, 7: OPH-02, NTC: no template as negative control (NC), 8: OPB13, 9: OPB-10, 10: OPB-03, 11: OPA-14, 12: OPA-08, 13: OPA06, 14: OPA-05, b. Screening of in vitro and mother plants using OPC-08 primers M: 100 bp ladder, 1-5 in vitro plant samples and 6-10 mother plants samples. c. Screening of in vitro and mother plants using OPB-03 primers M: 100 bp ladder, $1-5$ in vitro plant samples and 6-10 mother plant samples.

\section{Production of Active Constitutes by Callus Cultures \\ 2.1. Induction and maintenance of callus}

The leaf sections of $C$. spinosa var. deserti induced $100 \%$ of yellowish white friable callus on all MS media containing either 2,4-D individually or in combination with BA (Table 6 and Fig. 8). The highest mean fresh weight of callus reached $6.7 \mathrm{~g} / \mathrm{jar}$, on MS medium containing $2.0 \mathrm{mg} / 1$ 2,4-D plus 0.50 $\mathrm{mg} / \mathrm{l} \mathrm{BA}$ (Fig. 8a). It is noticed from the obtained data that using MS medium containing $0.5 \mathrm{mg} / \mathrm{l} \mathrm{BA}$ and those lacking BA; the response of leaf explants increased with the increase in 2,4-D concentration. The control medium 
without plant growth regulators did not induce any callus formation. It could be concluded from the obtained data that MS medium supplemented with 2.0 $\mathrm{mg} / 1$ 2,4-D plus $0.5 \mathrm{mg} / 1 \mathrm{BA}$ was the best medium for callus induction from leaf sections, it gave the maximum mean fresh weight of callus, comparing to the other tested media. From the obtained results, it could be concluded that 2,4-D played an important role in callus induction and maintenance. The supplementation of culture medium with three concentrations $(0.5,1$ or 2 $\mathrm{mg} / \mathrm{l})$ of 2,4-D alone or in combination with two concentrations $(0.1$ or 0.5 $\mathrm{mg} / \mathrm{l}$ ) of BA generally led to $100 \%$ of yellowish white friable callus production after two months of culture. However, the percentage of mass callus development varied depending on the plant growth regulators concentrations that were used. The positive effect of 2,4-D as an auxin in combination with BA as a cytokinin is supported by several reports (Perez Frances et al., 1995; Nowak and Miczynski, 2002 and Gang et al., 2003). These reports mentioned that in order to induce callus development, explants from Artichum mosses are usually cultured on a nutrient medium containing auxins and cytokinins. Also, MS medium amended with BA and 2,4-D has been reported to be extremely effective in inducing callus formation (Zeng et al., 2009), as cytokinins facilitated the effect of auxins in callus induction (Rao and Purohit, 2006). The superiority of 2,4-D is supported by Yang et al. (2008), who found that it is superior to NAA in callus induction of Leonurus heterophylus SW. Elmaghrabi et al. (2017) showed that high percentage $(95 \%)$ of callus induction was obtained from C. spinosa on MS medium supplemented with $1.2 \mathrm{mg} / 1$ 2,4-D plus maltose.

Table (6). The induction of callus from leaf sections of Capparis spinosa var. deserti cultured on MS medium containing 2,4-D with or without BA.

\begin{tabular}{|c|c|c|c|}
\hline \multicolumn{2}{|c|}{$\begin{array}{l}\text { Growth regulators } \\
\text { concentration }(\mathrm{mg} / \mathrm{l})\end{array}$} & \multirow{2}{*}{$\begin{array}{l}\text { Percentage of } \\
\text { callus induction } \\
(\%)\end{array}$} & \multirow{2}{*}{$\begin{array}{c}\text { Mean fresh } \\
\text { weight of callus } \\
\text { (g/ jar) }\end{array}$} \\
\hline 2,4-D & BA & & \\
\hline 0.0 & 0.0 & 0 & $0.1^{\mathrm{m}}$ \\
\hline 0.5 & 0.0 & 100 & $0.8^{1}$ \\
\hline 1.0 & 0.0 & 100 & $1.5^{\mathrm{j}}$ \\
\hline 2.0 & 0.0 & 100 & $2.3^{\mathrm{h}}$ \\
\hline 3.0 & 0.0 & 100 & $3.0^{\mathrm{g}}$ \\
\hline 0.5 & 0.1 & 100 & $5.0^{\mathrm{c}}$ \\
\hline 1.0 & 0.1 & 100 & $4.1^{\mathrm{e}}$ \\
\hline 2.0 & 0.1 & 100 & $1.2^{\mathrm{k}}$ \\
\hline 3.0 & 0.1 & 100 & $2.0^{\mathrm{i}}$ \\
\hline 0.5 & 0.5 & 100 & $3.5^{\mathrm{f}}$ \\
\hline 1.0 & 0.5 & 100 & $4.3^{\mathrm{d}}$ \\
\hline 2.0 & 0.5 & 100 & $6.7^{\mathrm{a}}$ \\
\hline 3.0 & 0.5 & 100 & $5.2^{\mathrm{b}}$ \\
\hline
\end{tabular}

Egyptian J. Desert Res., 71, No. 2, 209-243 (2021) 


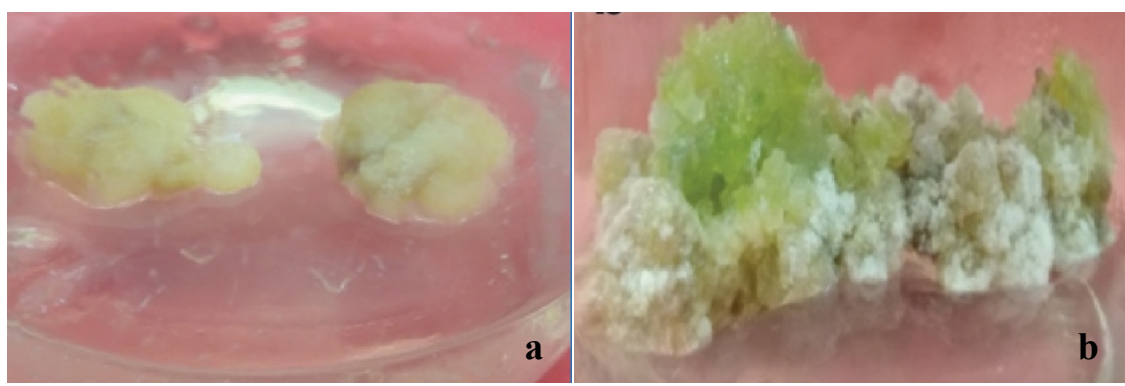

Fig. (8). Callus of Capparis spinosa var. deserti induced on MS medium supplemented with $2 \mathrm{mg} / 1$ 2,4-D plus $0.5 \mathrm{mg} / 1 \mathrm{BA}$. a. Callus initiation; b. Callus proliferation.

\subsection{Effect of elicitation and precurarization on callus growth rate}

By comparing the effect of different applied concentrations of two elicitors; SA (0.00, 25, 50 and $100 \mathrm{ppm})$ and MeJA (5, 10 and $20 \mathrm{ppm})$ and the precursor Phe (25, 50 and $100 \mathrm{ppm})$, data in table (7) show that the highest mean fresh weight of callus, was obtained on the medium contained $50 \mathrm{ppm}$ Phe, and their values reached $7.86 \mathrm{~g} / \mathrm{jar}$ (Fig. 8b). On the other hand, the lowest callus formation was observed on MS medium supplemented with 50 ppm SA (3.04 g/jar). The dry weight of callus varied significantly with the different types and concentrations of additives. The maximum dry weight $(0.72 \mathrm{~g} / \mathrm{g}$ fresh wt.) was also produced on $50 \mathrm{ppm}$ Phe, followed by the medium contained $100 \mathrm{mg} / 150 \mathrm{ppm}$ Phe. While, the minimum dry weight of callus $(0.17 \mathrm{~g} / \mathrm{g}$ fresh wt.) was obtained with control (without elicitors and precursor

Table (7). Effect of the elicitors; salicylic acid and methyl jasmonate and the precursor phenylalanine on biomass, qurecetin and rutin accumulation in the callus of Capparis spinosa var. deserti.

\begin{tabular}{|c|c|c|c|c|}
\hline \multicolumn{3}{|c|}{$\begin{array}{c}\text { Concentrations of elicitors and } \\
\text { precursor }(\mathrm{ppm})\end{array}$} & \multirow{2}{*}{$\begin{array}{c}\text { Mean fresh } \\
\text { weight of callus } \\
\text { (g/ jar) }\end{array}$} & \multirow{2}{*}{$\begin{array}{c}\text { Mean dry weight } \\
\text { of callus } \\
\text { (g/g fresh wt.) }\end{array}$} \\
\hline $\mathbf{S A}$ & MeJA & Phe & & \\
\hline 0 & 0 & 0 & $3.34^{\mathrm{f}}$ & $0.17^{\mathrm{e}}$ \\
\hline 25 & 0 & 0 & $3.98^{\mathrm{de}}$ & $0.24^{\text {bd }}$ \\
\hline 50 & 0 & 0 & $3.04^{\mathrm{f}}$ & $0.18^{\text {be }}$ \\
\hline 100 & 0 & 0 & $3.20 \mathrm{~b}^{\mathrm{f}}$ & $0.19^{\text {de }}$ \\
\hline 0 & 5 & 0 & $4.66^{c}$ & $0.36^{\mathrm{c}}$ \\
\hline 0 & 10 & 0 & $4.34^{\mathrm{cd}}$ & $0.31^{\mathrm{c}}$ \\
\hline 0 & 20 & 0 & $3.48^{\text {ef }}$ & $0.19^{\text {de }}$ \\
\hline 0 & 0 & 25 & $6.94^{\mathrm{b}}$ & $0.61^{\mathrm{b}}$ \\
\hline 0 & 0 & 50 & $7.86^{\mathrm{a}}$ & $0.72^{\mathrm{a}}$ \\
\hline 0 & 0 & 100 & $7.14^{\mathrm{b}}$ & $0.67^{\mathrm{a}}$ \\
\hline
\end{tabular}




\subsection{Effect of elicitation and precurarization on rutin and quercetin biosynthesis}

Data presented in fig. (9) reveal that two HPLC flavonoids, rutin and quercetin were detected after 30 days post elicitation and precurarization of C. spinosa var. deserti calli. Harvested callus cultures were able to accumulate both rutin and quercetin. The results showed that among all treated callus cultures, the highest rutin content detected with 100 and 50 ppm SA (83.98 and $72.41 \mu \mathrm{g} / \mathrm{g} \mathrm{FW}$, respectively), followed by Phe precurarization treatment at concentrations of 50,100 ppm (51.18 and $46.33 \mu \mathrm{g} / \mathrm{g} \mathrm{FW}$, respectively), compared with control treatment that recorded $7.81 \mu \mathrm{g} / \mathrm{g}$ FW. After 30 days of callus precurarization with Phe at concentrations of 50 and $100 \mathrm{ppm}$, quercetin content was accumulated significantly (7.37 and $6.25 \mu \mathrm{g} / \mathrm{g} \mathrm{FW}$ ) more than all the other treatments including SA, MeJA and control. In the same manner, elicitation of $C$. spinosa var. deserti calli with SA at concentrations of 25,50 ppm showed significant increase in quercetin content of approximately 3.9 and $2.7 \mu \mathrm{g} / \mathrm{g}$ the unit, respectively), compared to the control treatment which exhibited the lowest quercetin content $(0.14 \mu \mathrm{g} / \mathrm{g}$ FW). Elicitation with MeJA at concentrations of 10 and $20 \mathrm{ppm}$, slightly increased accumulation level of both rutin and quercetin in calli cultures, compared to control calli (Fig. 9). These findings agree with those of El-Ashry et al. (2019), who reported significant enhancement in flavonoid compounds after chemical feeding with different elicitors and precursors. SA and MeJA have a great role in the regulation of plant growth and development as hormone-like substances (Kang et al., 2006 and El-Ashry et al., 2019) where $\mathrm{SA}, \mathrm{MeJA}$ and Phe induces gene regulation associated to the secondary metabolites biosynthesis (Taguchi et al., 2001 and El-Ashry et al., 2019) and affect diversely on the plant physiological processes (Malabadi et al., 2008a; b and El-Ashry et al., 2019). The obtained results about callus grown on nonelicited MS medium by any elicitors or stimulator compounds negatively affected both rutin and quercetin content are confirmed by Goda et al. (2017). Phe as an amino acid accelerates primer metabolism operation during phosphor enol pyruvic acid conversion to pyruvic acid; this acid act as key compound in several biochemical pathways (Goda et al., 2017 and Noviyanti et al., 2017); Phe as an aromatic amino acid possess function as bio block of protein and has an effect on hormone synthesis such as salicylate and auxin (Tzin and Galili, 2010).

Egyptian J. Desert Res., 71, No. 2, 209-243 (2021) 
a

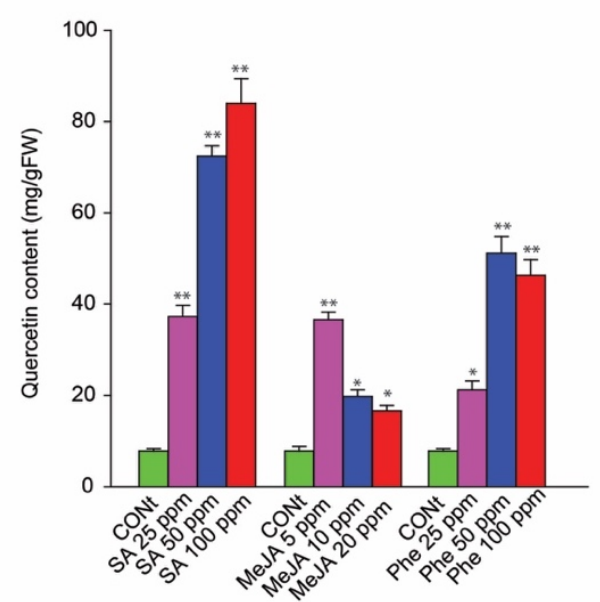

b

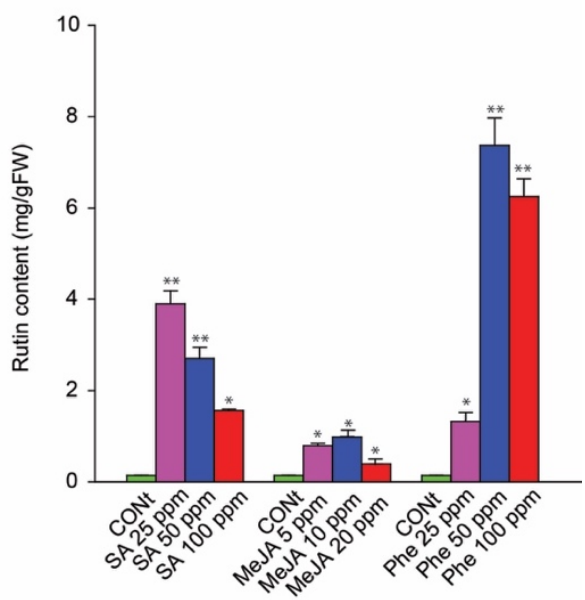

Fig. (9). Quercetin and rutin contents in callus of Capparis spinosa var. deserti treated with SA, MeJA and Phe. a. quercetin content $(\mu \mathrm{g} / \mathrm{g} \mathrm{FW}) ; \mathbf{b}$. rutin content $(\mu \mathrm{g} / \mathrm{g} \mathrm{FW})$. Error bars indicate standard error values. Single $(* P<0.05)$ and double $(* * P<0.01)$ asterisks denote statistically significant differences.

\subsection{Expression analysis of rutin and quercetin biosynthetic related-genes in $C$. spinosa var. deserti treated with SA, MeJA and Phe}

After elicitation and precurarization, total RNA was extracted from frozen callus of $C$. spinosa var. deserti and the first-strand cDNA were synthesized. To explore the mechanism controlling rutin and quercetin biosynthesis in caper plants, transcript levels of two identified genes were examined in callus of control and treated with 5, 10, 20 ppm MeJA and 25, $50,100 \mathrm{ppm}$ SA or Phe using qRT-PCR method. Interestingly, most of the examined calli samples exhibited high positive significant response to the different concentrations of the elicitors SA and MeJA as well as Phe precursor. Transcript results exhibited dramatic increase of 4CL levels after elicitation treatment of callus with the different concentrations of SA; 25, 50 and 100 ppm approximately 2, 3, 4-fold-changes, respectively, compared to nontreated calli (Fig. 10a). In line with 4CL, elicitation with SA results in increased transcription level of RT almost 1.6, 2.6, 2.4-fold-changes at the different concentrations of 25, 50 and $100 \mathrm{ppm}$ (Fig. 7b). In the same manner, precurarization with Phe showed significant accumulation in the transcript levels of both biosynthetic genes 4CL and RT (Fig. 7a and b). Elicitation of caper calli with MeJA at different concentrations; 5, 10 and 20 ppm slightly, elevated both 4CL and RT transcription levels (Fig. 10a and b). The obtained results of transcript analysis for both 4CL and RT genes in caper calli was confirmed by Hou et al. (2014) and Goda et al. (2017), who indicated 
significant increase in response to elicitation or precurarization with different concentrations of SA, MeJA and Phe. 4-coumaroyl CoA ligase (4CL) and flavonol-3-O-glucoside L-rhamnosyltransferase (RT) are master key enzymes of flavonoids biosynthesis in plants. SA, MeJA and Phe induced up-regulation of $4 \mathrm{CL}$ and RT activities that consequently increased flavonoid production (Horvath et al., 2007 and Kianersi et al., 2020). Elicitation with SA and MeJA or precurarization with Phe exhibited high efficiency in secondary metabolites depends on many factors such as the concentration and mode of application of these compounds endogenous level of these compounds in plant, the type of tissue to be treated, as well as the developmental stage of the plant (Yang et al., 2008). Taken together, investigations of the present studies indicate that accumulation and biosynthesis of secondary metabolites are usually in response to various environmental stimuli, biotic and abiotic such as Phe, SA and MeJA (Horvath et al., 2007). As a general rule, undifferentiated tissues growing in synthetic media show a greatly reduced capacity for secondary metabolism (George, 1993), this agreed with the previous results in which the highest yield of rutin and qurecetin was in the leaves of the wild plant.

a

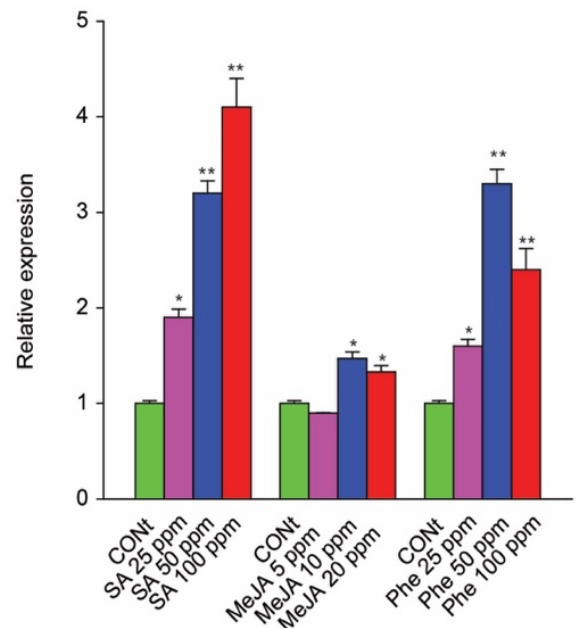

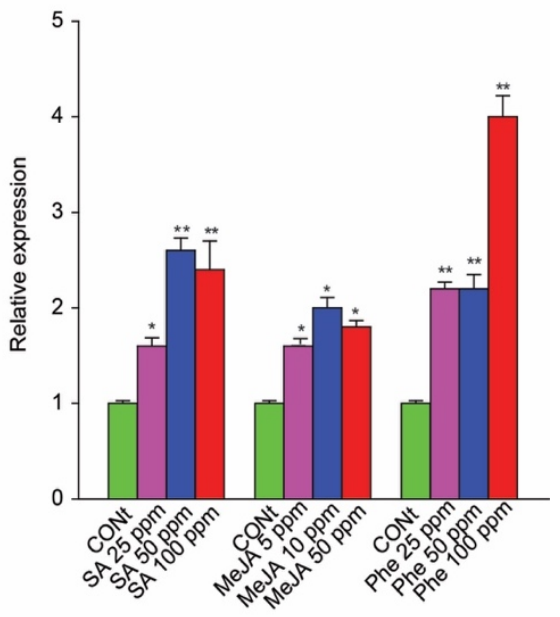

Fig. 10. Expression levels of rutin and quercetin biosynthesis-related genes in callus of Capparis spinosa var. deserti after elicitation and precurarization applications. a Expression levels of 4-coumaroyl CoA ligase (4CL) after SA and MeJA elicitation and Phe precurarization; b. Expression levels of flavonol-3-O-glucoside L-rhamnosyl transferase (RT) after SA and MeJA elicitation and Phe precurarization. Transcription levels for each gene was normalized based on the $\mathrm{Ct}$ values of Ubiquitin as a reference gene. Error bars indicate standard error values. Single $(* P<0.05)$ and double $(* * P$ $<0.01)$ asterisks denote statistically significant differences.

Egyptian J. Desert Res., 71, No. 2, 209-243 (2021) 


\subsection{Evaluation the percentage of free radical scavenging capacity in callus cultures in response to chemical feeding}

Scavenging capacity (RSC) was evaluated by measuring the scavenging activity of C. spinosa var. deserti callus extracts on 2,2-diphenyl1picrylhydrazyl (DPPH) radicals. Capparis sp. contains considerable amounts of bioactive substances such as phenols and bio- flavonoids as reported previously (Soyler and Khawar, 2007). In this part of the study, extracts calli were examined for their hydrogen donating ability for binding with the DPPH free radical to reduce its stability, changing from green color to the yellow color according to the antioxidant activity determination. The effects of SA, MAJe and Phe with their different concentrations in calli culture medium were examined. Their efficacy of discoloration which in turn indicates to their radical scavenging capacity for calli were recorded (Fig. 11a). The obtained data revealed that all callus extracts exhibited significantly different antioxidant activity values for reduction DPPH free radical scavenging during the harvested period of culturing. The considerable increment in reduction of DPPH was attained with using SA at concentration of $25 \mathrm{ppm}(82.5 \pm 1.07 \%)$ and Phe at concentrations of $100 \mathrm{ppm}$ and $25 \mathrm{ppm}(82.1 \pm 1.09 \%$ and $77.6 \pm$ $0.76 \%$, respectively), followed by SA at concentration of $50 \mathrm{ppm}$ and control (76.52 $\pm 0.73 \%$ and $76.52 \pm 0.75 \%$, respectively). In contrast, Phe at concentration of $50 \mathrm{ppm}$ and MAJe at concentration of $20 \mathrm{ppm}$ recorded lower values $(63.77 \pm 0.53 \%$ and $64.63 \pm 0.53 \%$, respectively), post elicitation and precurarization. According to the attained results, it is observed that the application of either SA or the Phe with their different concentrations enhanced the inhibition of DDPH rather than the control. Therefore, it is recommended to add one of them to $C$. spinosa var. deserti calli culture medium particularly SA at $25 \mathrm{ppm}$ and Phe at $100 \mathrm{ppm}$, which is more potent than MeJA for stimulating the capacity of calli extracts to donate hydrogen atom for the enhancement of their antioxidant activity. Fortunately, several studies have detailed the effect of different elicitors and precursors on DPPH free radical scavenging capacity in different plants, including gardenia, shaftal clover, Ceropegia thwaitesii, sanguinaria and purple basil (RodriguesBrandão et al., 2014; Muthukrishnan et al., 2018; El-Ashry et al., 2019; Twaij et al., 2019 and Nazir et al., 2020). The correlation between phenolic and flavonoid content was statistically evaluated with antioxidant activity that regulates DPPH content in plant cell (El-Ashry et al., 2019). 


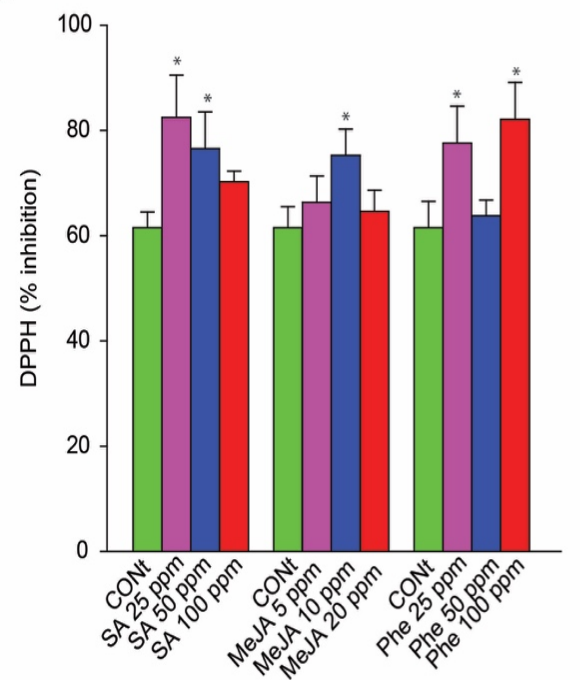

b

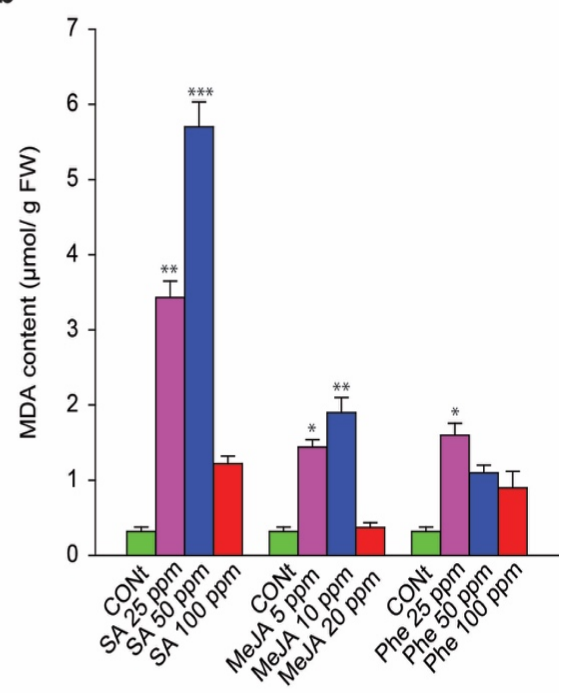

Fig. (11). Effect of elicitation and precurarization treatments on biochemical parameters of $C$. spinosa var. deserti callus. a. Free radical scavenging activity as DPPH (\% inhibition); b. Malondialdehyde (MDA) content after elicitation and precurarization treatments. The data shown are the mean $\pm \operatorname{SE}(n=6)$. Single $(* P<0.05)$ and double $(* * P<0.01)$ asterisks denote statistically significant differences.

\subsection{Effect of elicitation and precurarization treatments on malondialdehyde content}

Irrespective of the elicitation and precurarization treatments, levels of MDA in C. spinosa var. deserti increased in varying degrees, 30 days after chemical feeding (Fig. 11b). Elicitation with SA at concentrations of 25 and $50 \mathrm{ppm}$ exhibited the highest values of MDA $(3.43 \pm 0.07$ and $5.7 \mu \mathrm{mol} / \mathrm{g} \mathrm{FW}$ \pm 0.1 , respectively), followed by MeJA at $10 \mathrm{ppm}$ that showed $1.9 \pm 0.03$ $\mu \mathrm{mol} / \mathrm{g}$ FW seven days-post elicitation. Conversely, control treatment recorded lower values of MDA. Previous studies conducted on different plant species confirmed that despite the positive role of stimulating flavonoid compounds, it coincided with a noticeable increase in the level of MDA (Draper and Hadley, 1990; Esterbauer and Cheeseman, 1990; Chong et al., 2004 and Ayala et al., 2014). Elicitation in plants can induce the production of reactive oxygen species (ROS) such as hydrogen peroxide $\left(\mathrm{H}_{2} \mathrm{O}_{2}\right)$ and products of lipid peroxidation as MDA (Hancock et al., 2002).

\section{CONCLUSION}

Based on its medicinal nature and high accessibility, C. spinosa var. deserti can be a vital nutritional nominee to be inclusive in the daily diet in order to prevent Alzheimer's disease. A reproducible, safe and credible 
protocol for micropropagation of $C$. spinosa var. deserti through the high shoot multiplication rate and rooting was achieved in the present study. The obtained results suggested that using MS medium fortified with $2.0 \mathrm{mg} / 12 \mathrm{iP}$ exhibited the maximum rate of proliferation and TDZ at $0.75 \mathrm{mg} / 1$ induced shoot organogenesis. Metabolic results showed significant accumulation in rutin and qurecetin after calli elicitation with SA and MeJA as well as the precurarization with Phe. Moreover, the genetic stability analysis using the RAPD primers confirmed that there was no difference between the genotypes of the plant. Furthermore, transcript levels of the flavonoids biosynthetic genes $4 \mathrm{CL}$ and RT in caper calli were significantly up-regulated in response to different concentrations of SA and MeJA elicitation and Phe precurarization. This study paves the way to conserve other endangered medicinal plants.

\section{ACKNOWLEDGEMENTS}

All praises and thanks be to Allah. The authors would like to thank Prophet Mohamed, who asked Muslims to do beneficial work for all human without discrimination. The authors would like to thank Prof. Mahmoud Sakr for his suggestions; Prof. Nahla El-Ashmawy and Dr. Eman Khames for their technical support to the research and Dr. Mahmoud El-Habaaq for advice on Statistics. The authors also extend their gratitude to Academy of Scientific Research and Technology (ASRT), Ministry of Higher Education; Tanta University and Desert Research Center (DRC), Egypt for providing the opportunity to pursue studies. This work was supported by the Initiative of Development Center, Academy of Scientific Research and Technology (ASRT).

\section{REFERENCES}

Abou Hadid, A., B. Kamal, A. Jabarine and A. Kader (2004). Proposal for expanding the crop mandate of ICARDA to include horticultural crops. ICARDA, Syria, $38 \mathrm{p}$.

Al-Safadi, B. and R. Elias (2011). Improvement of caper (Capparis spinosa L.) propagation using in vitro culture and gamma irradiation. Scientia Horticulturae, 127 (3): 290-297.

Attia, A.O., E.D.S. Dessoky, Y.M. Al-Sodany and I.A. Ismail (2017). Ex situ preservation for some endemic and rare medicinal plants in Taif, KSA. Biotechnol. Equip., 31: 912-920.

Ayala, A., M.F. Muñoz and S. Argüelles (2014). Lipid peroxidation: production, metabolism, and signalling mechanisms of malondialdehyde and 4-hydroxy-2-nonenal. Oxid. Med. Cell. Longev., 2014: Article ID 360438.

Barbera, G. and R. Di Lorenzo (1984). The caper culture in Italy. Acta Hortic., 144: 167-171. 
Ben Salem, A.B., H. Zemni and A. Ghorbel (2001). Propagation of caper (Capparis spinosa L.) by herbaceous cuttings and in vitro culture. Agricultura Mediterránea, 131 (1/2): 42-48.

Bhargava, R., P. Verma, P.L. Saroj and N. Chauhan (2006). Propagation of Capparis decidua. Indian Forester, 132 (6): 737-745.

Bhowmik, S.S., S. Kumaria, S.R. Rao and P. Tandon (2009). High frequency plantlet regeneration from rhizomatous buds in Mantisia spathulata Schult. and Mantisia wengeri Fischer and analysis of genetic uniformity using RAPD markers. Indian J. Exp. Biol., 47: 140-146.

Boulos, L. (2009). In: "Flora of Egypt Checklist" Revised Annotated Edition. Al Hadara Publishing, Cairo, Egypt.

Brand, W., M.E. Cuvelier and C. Berset (1995). Use of a free radical method to evaluate antioxidant activity. LWT-Food Sci. Technol., 28: 25-30.

Carra, A., M. Sajeva, L. Abbate, M. Siragusa, F. Sottile and F. Carimi (2012). In vitro plant regeneration of caper (Capparis spinosa) from floral explants and genetic stability of regenerants. Plant Cell Tissue and Organ Culture, 109: 373-381.

Chedraoui, S., A. Abi-Rizk, M. El-Beyrouthy, L. Chalak, N. Ouaini and L. Rajjou (2017). Capparis spinosa L. in a systematic review: a xerophilous species of multi values and promising potentialities for agrosystems under the threat of global warming. Front. Plant Sci., 8: 1845.

Chong, T.M., M.A. Abdullah, N.M. Fadzillah, O.M. Lai and N.H. Lajis (2005). Jasmonic acid elicitation of anthraquinones with some associated enzymic and non-enzymic antioxidant responses in Morinda elliptica. Enzyme Microb. Technol., 36: 469-477.

Deora, N.S. and N.S. Shekhawat (1995). Micropropagation of Capparis decidua (Forsk.) Edgew-A tree of arid horticulture. Plant Cell Rep., 15: 278-281.

De-Souza, F.S.A., K.S. da-Costa and J.B. Martins (2021). Analysis of conformational, structural, magnetic, and electronic properties related to antioxidant activity: revisiting flavan, anthocyanidin, flavanone, flavonol, isoflavone, flavone, and flavan-3-ol". ACS Omega, 6 (13): 8908-8918.

Draper, H.H. and M. Hadley (1990). Malondialdehyde determination as index of lipid peroxidation. Meth. Enzymol., 186B: 421-431.

Dulf, F.V., D.C. Vodnar, E.H. Dulf and M.I. Toşa (2015). Total phenolic contents, antioxidant activities, and lipid fractions from berry Pomaces obtained by solid-state fermentation of two Sambucus species with Aspergillus niger. J. Agric. Food Chem., 63: 3489-3500.

Eizaguirre, C. and M. Baltazar-Soares (2014). Evolutionary conservationevaluating the adaptive potential of species. Evol. Appl., 7: 963-967.

Egyptian J. Desert Res., 71, No. 2, 209-243 (2021) 
El-Ashry, A.AL., A.M.M. Gabr, N.M. Arafa et al. (2019). Rutin accumulation in gardenia calli cultures as a response to phenyl alanine and salicylic acid. Bull. Natl. Res. Cent., 43: 141.

Elmaghrabi, A.M., E. Abughnia and S. Hamoud (2017). In vitro propagation of the wild medicinal plant, caper (Capparis spinosa L.). Afr. J. Biotechnol., http://www.academicjournals.org/AJB.

Esterbauer, H., and K.H. Cheeseman (1990). Determination of aldehydic lipid peroxidation products: malonaldehyde and 4hydroxynonenal. Methods. Enzymol., 186: 407-421.

Ewas, M., Y.Q. Gao, S. Wang, X. Liu, H. Zhang, E. Nishawy, F. Ali, R. Shahzad, K. Ziaf, H. Subthain, C. Martin and J. Luo (2016). Manipulation of tomato SlMXl for enhanced carotenoids accumulation and drought resistance in tomato. Sci. Bull., 61: 14131418.

Ewas, M., Y.Q. Gao, F. Ali, E.M. Nishawy, R. Shahzad, H. Subthain, M. Amar, C. Martin and J. Luo (2017). RNA-Seq reveals mechanisms of SlMXI for enhanced carotenoids and terpenoids accumulation along with stress resistance in tomato. Sci. Bull., 62 (1): 476-485.

Feliciano, R.P., S. Pritzel, C. Heiss and A. Rodriguez-Mateos (2015). Flavonoid intake and cardiovascular disease risk. Curr. Opin. Food Sci., 2: 92-99.

Gang, Y.Y., G.S. Du, D.J. Shi, M.Z. Wang, X.D. Li and Z.L. Hua (2003). Establishment of in vitro regeneration system of the Atrichum mosses. Acta Botanica Sinica, 45 (12): 1475-1480.

George, E.F. (1993). In: "Plant Propagation by Tissue Culture", Part 1, $2^{\text {nd }}$ ed., Exegetics Ltd., pp. 420-426.

Giri, G. and Zaheer, M. (2016). Chemical elicitors versus secondary metabolite production in vitro using plant cell, tissue and organ cultures: recent trends and a sky eye view appraisal. Plant Cell Tiss. Org. Cult., 126 DOI: $10.1007 / \mathrm{s} 11240-016-0985-6$

Goda, S.M., S.A. Ahmed, F. El Sherif, H.A. Hassanean and A.K. Ibrahim (2017). Genetically stable plants with boosted flavonoids content after in vitro regeneration of the endangered Capparis spinosa L. Glob. Drugs Therap., 2 (4): 1-7.

Gruère, G.P., A. Giuliani and M. Smale (2019). Marketing underutilized plant species for the benefit of the poor: a conceptual framework. IFPRI Environmental and Protection Technology EPT 2006, Discussion Paper No. 154.

Hancock, J.T., R. Desikan, A. Clarke, R.D. Hurst and S.J. Neill (2002). Cell signaling following plant/pathogen interactions involves the generation of reactive oxygen and reactive nitrogen species. Plant Physiol. Biochem., 40: 611-617. 
Hare, K., A. Mahdi, S. Dhurendra, S. Udayvir, C. Nitesh, E. Maliheh and K.S. Radha (2016). Somaclonal variations and their applications in horticultural crops improvement. 3 Biotech., 6: 54.

Hartmann, H.T. and D.F. Kester (1983). In: "Plant Propagation: Principles and Practices". $4^{\text {th }}$ ed. Prentice Hall, Iwc. England, New Jersey.

Hassan, H.M.S. and M.A.I. Abdelkader (2015). Effect of some factors on caper micropropagation. Journal of Plant Production, Mansoura Univ., 6 (10): $1693-1703$.

Hassanein, R.A., A.F. Gabr, M.A. Ahmed and Gh.A. Hegazi (2008). Micropropagation of Capparis cartilaginea. Catrina, 3 (3): 25-32.

Hegazi, Gh.A., S.R. Eid and M.M. Sharaf (2011). Micropropagation for conservation of two rare Capparis species from Egypt. Catrina, 6: 29-39.

Horvath, E., G. Szalai and T. Janda (2007). Induction of abiotic stress tolerance by salicylic acid signaling. J. Plant Growth Regul., 26: 290300 .

Hou, S., Z. Sun, B. Linghu, Y. Wang, K. Huang, D. Xu and Y. Han (2014). Regeneration of buckwheat plantlets from hypocotyl and the influence of exogenous hormones on rutin content and rutin biosynthetic gene expression in vitro. Plant Cell Tiss. Organ Cult., 120: 1159-1167.

IPBES (2019). Summary for policymakers of the global assessment report on biodiversity and ecosystem services of the intergovernmental sciencepolicy platform on biodiversity and ecosystem services, IPBES Secretariat, Bonn, Germany.

Inocencio, C., F. Alcaraz, F. Calderón, C. Obón and D. Rivera (2002). The use of floral characters in Capparis sect. Capparis' to determine the botanical and geographical origin of capers. Eur. Food Res. Technol., 214 (4): 335-339.

Jan, R., S. Asaf, M. Numan, Lubna and K.M. Kim (2021). Plant secondary metabolite biosynthesis and transcriptional regulation in response to biotic and abiotic stress conditions. Agronomy, 11: 968.

Jiao, J., Q.Y. Gai, W. Wang M. Luo, Y.G. Zu, Y.J. Fu and W. Ma (2016). Enhanced astragaloside production and transcriptional responses of biosynthetic genes in Astragalus membranaceus hairy root cultures by elicitation with methyljasmonate. Biochem. Eng. J., 105: 339-346.

Kang, S.H., L. Kim, H. Le, J.Y. Choi, H. Heu and C.J. Oh (2006). Over expression of Arabidopsis of a plasma membrane-targeting glutamate receptor from small radish increases glutamate-mediated $\mathrm{Ca}^{+2}$ influx and delays fungal infection. Mol. Cell, 21 (3): 418-427.

Kereša, S., D. Stankovi'c, K. Batelja Lodeta, J.I. Habuš, S. Bolari'c, M. Bari'c and A. Bošnjak Mihovilovi'c (2019). Efficient protocol for the in vitro plantlet production of caper (Capparis orientalis Veill.) from the East Adriatic Coast. Agronomy, 9: 303.

Egyptian J. Desert Res., 71, No. 2, 209-243 (2021) 
Kianersi, F., M.R. Abdollahi, A. Mirzaie-asl et al. (2020). Identification and tissue-specific expression of rutin biosynthetic pathway genes in Capparis spinosa elicited with salicylic acid and methyl jasmonate. Sci. Rep., 10: 8884.

Kotnala, M., G.S. Chakraborthy and A. Mazumder (2011). Lagerstroemia species: a current review. Int. J. Pharm. Technol. Res., 5: 906-909.

Levizou, E., P. Drilias and A. Kyparissis (2004). Exceptional photosynthetic performance of Capparis spinosa L. under adverse conditions of Mediterranean summer. Photosynthetica, 42: 229-235.

Livak, K.J. and TD. Schmittgen (2001). Analysis of relative gene expression data using real-time quantitative PCR and the 2(-Delta Delta C(T)) Method. Methods, 25: 402-408.

Malabadi, R.B., J. Teixeira da Silva and K. Nataraja (2008a) A new approach involving salicylic acid and thin cell layers for cloning mature trees of Pinus roxburghii (Chir Pine). Am. J. Plant Sci. Biotechnol., 2 (2): 56-59.

Malabadi, R.B., J. Teixeira da Silva and K. Nataraja (2008b) Salicylic acid induces somatic embryogenesis from mature trees of Pinus roxburghii (Chir pine) using TCL Technology. Tree and Forestry Science and Biotechnology, 2 (1): 34-39.

Madhava Rao, K.V. and T.V.S. Sresty (2000). Antioxidative parameters in the seedlings of pigeonpea (Cajanus cajan (L.) Millspaugh) in response to $\mathrm{Zn}$ and Ni stresses. Plant Sci., 157: 113-128.

Martins, M., D. Sarmento and M.M. Oliveira (2004). Genetic stability of micropropagated almond plantlets as assessed by RAPD and ISSR markers. Plant Cell Rep., 23: 492-496.

Mehrabani, L.V. (2016). In vitro micropropagation of two native Capparis spinosa L. cultivars from Iran. Biological Forum, 8 (2): 144-149.

Muthukrishnan, S., T.S. Kumar, A. Gangaprasad, F. Maggi and M.V. Rao (2018). Phytochemical analysis, antioxidant and antimicrobial activity of wild and in vitro derived plants of Ceropegia thwaitesii Hook - An endemic species from Western Ghats. India. J. Genet. Eng. Biotechnol., 16 (2): 621-630.

Murashige, T. (1974). Plant propagation through tissue culture. Annual Review of Plant Physiology, 25: 135-166.

Murashige, T. (1977). Clonal Crops Through Tissue Culture. In: "Plant Tissue Culture and its Biotechnological Application" (Barz, W. et al. Eds), Springer-Verlag, Berlin, pp. 392-403.

Murashige, T. and F. Skoog (1962). A revised medium for rapid growth and bioassays with tobacco tissue cultures. Plant Physiology, 15: 473-497.

Musallam, I., M. Duwayri and R. Shibli (2011). Micropropagation of caper from wild plant. Functional Plant Science and Biotechnology, 5: 1721. 
Noviyanti, R., R.L.K. Sari, A.N. Kristanti, A. Yachya, S. Yosephine and Y.S.W. Manuhara (2017). Biomass and flavonoid production of Gynura procumbens adventitious roots induced by sucrose, phenylalanine and tyrosine. Biosci. Res., 14 (4): 934-941.

Nowak, B. and K. Miczynski (2002). The course and efficiency of organogenesis on leaf explants of Plum Wegierka Zwykla (Prunus domestica L.) induced by cytokinins. Electronic Journal of Polish Agricultural Universities-Biotechnology, 5: 120-124.

Nazir, M., M. Asad Ullah, S. Mumtaz, A. Siddiquah, M. Shah, S. Drouet, C. Hano and B.H. Abbasi (2020). Interactive effect of melatonin and UV-C on phenylpropanoid metabolite production and antioxidant potential in callus cultures of purple basil (Ocimum basilicum $\mathrm{L}$. var purpurascens). Molecules, 25: 1072.

Ölmez, Z., Z. Yahyo and O. Üçler (2004). Effect of $\mathrm{H}_{2} \mathrm{SO}_{4}, \mathrm{KNO}_{3}$ and $\mathrm{GA}_{3}$ treatments on germination of caper (Capparis ovate Desf.) seeds. Pakistan J. Bio. Sci., 7 (6): 879-882.

Padulosi, S., T. Hodgkin, J.T. Williams and N. Haq (2002). Underutilised Crops: Trends, Challenges and Opportunities in the 21st Century. In: "Managing Plant Genetic Diversity". CAB International: Wallingford, UK, pp. 323-338.

Parida, R., S. Mohanty and S. Nayak (2011). Evaluation of genetic fidelity of in vitro propagated greater galangal (Alpinia galanga 1 .) using DNA based markers. Int. J. Plant Animal Env. Sci., 1: 123-133.

Perez Frances, J.F., A.J. Exposito and J.A. Rodriguezperez (1995). Effect of different factors on in vitro multiplication of Leucadendron 'Safari Sunset' (Proteaceae). Acta Hortic., 387: 115-120.

Panche, A.N., A.D. Diwan and S.R. Chandra (2016). Flavonoids: an overview. J. Nutr. Sci., 5: e47.

Qian, Z.G., Z.J. Zhao, Y. Xu, X. Qian and J.J. Zhong (2004). Novel chemically synthesized hydroxyl-containing jasmonates as powerful inducing signals for plant secondary metabolism. Biotechnol. Bioeng., 86: 809-816.

Ramezani-Gask, M., M. Bahrani and A. Shekafandeh (2008). A comparison of different propagation methods of common Caper-bush (Capparis spinosa L.) as a new horticultural crop. Int. J. Plant Dev., 2:106-110.

Rao, M.S. and S.D. Purohit (2006). In vitro shoot bud differentiation and plantlet regeneration in Celastrus paniculatus Willd. In Vitro Cell. Dev. Biol. - Plant, 50: 501-506.

Rodrigues-Brandão, I., A.M. Kleinowski, A.M. Einhardt, M.C. Lima, L. Amarnte, J.A. Peters and E.J.B. Braga (2014). Salicylic acid on antioxidant activity and betacyan in production from leaves of Alternanthera tenella. Ciencia Rural, 44: 1893-1898.

Egyptian J. Desert Res., 71, No. 2, 209-243 (2021) 
Sharma, H. (2014). Role of growth regulators in micropropagation of woody plants-a review. International J. Advanced Research, 5 (2): 23782385.

Shan, X., J. Cheng, K.1. Chen, Y.M. Liu and L. Juan (2017). Comparison of lipoxygenase, cyclooxygenase, xanthine oxidase inhibitory effects and cytotoxic activities of selected flavonoids. DEStech Trans. Environ. Energy Earth Sci., doi: 10.12783/dteees/gmee2017/16624.

Smith, R.H. and T. Murashige (1970). In vitro development of the isolated shoot apical meristems of angiosperms. Am. J. Bot., 57: 562-568.

Soyler, D. and K.M. Khawar (2007). Seed germination of caper (Capparis ovata var. herbacea) using naphthalene acetic acid and gibberellic acid. Int. J. Agric. Biol., 1 (9): 35-37.

Taguchi, G., T. Yazawa, N. Hayashida and M. Okazaki (2001). Molecular cloning and heterologous expression of novel glucosyltransferases from tobacco cultured cells that have broad substrate specificity and are induced by salicylic acid and auxin. Eur. J. Biochem., 268: 40864094.

Torres, K.C. (1989). Tissue Culture Media Composition and Preparation. In: "Tissue Culture Techniques for Horticultural Crops". Chapman and Hall, New York, pp. 26-51.

Twaij, B.M., Jazar Z.H. and M.N. Hassan (2019). The effects of elicitors and precursor on in-vitro cultures of Trifolium resupinatum for sustainable metabolite accumulation and antioxidant activity. Biocatal. Agric. Biotechnol., 22: 101337.

Tzin, V. and G. Galili (2010). The biosynthetic pathways for shikimate and aromatic amino acids in Arabidopsis thaliana. The Arabidopsis Book, 8: $130-132$.

Tyagi, P. and S.L. Kothari (1997). Micropropagation of Capparis decidua through in vitro shoot proliferation on nodal explants of mature tree and seedling explants. J. Plant Biochem. Biotech., 6: 19-23.

Tyagi, P., S. Khanduja and S.L. Kothari (2010). In vitro culture of Capparis decidua and assessment of clonal fidelity of the regenerated plants. In Vitro Cell. Dev. Biol. - Plant, 54 (1): 126-130.

Ullah, A, S. Munir, S.L. Badshah, N. Khan, L. Ghani, B.G. Poulson, A-H. Emwas and M. Jaremko (2020). Important flavonoids and their role as a therapeutic agent. Molecules, 25 (22): 5243.

Venkatachalam, L., R.V. Sreedhar and N. Bhagyalakshmi (2007). Genetic analysis of micropropagated and regenerated plantlets of banana as assessed by RAPD and ISSR markers. In Vitro Cell. Dev. Biol. Plant, 43: 267-274.

Yang, J., Z.C. Gong and X. Tan (2008). Induction of callus and extraction of alkaloid from Yi Mu Cao (Leonurus heterophylus Sw.) culture. Afr. J. Biotechnol., 7 (8): 1157-1162. 
Yildirim, Z. and E. Bayram (2001). Propagation of caper by seed, cuttings, or by tissue culture. Turkish J. Field Crops, 6 (1): 6-13.

Zeng, F.S., W.W. Wang, Y.G. Zhan and Y. Xin (2009). Establishment of the callus and cell suspension culture of Elaeagnus angustifolia for the production of condensed tannins. Afr. J. Biotechnol., 8 (19): 50055010.

Zidani, S., A. Ferchichi and M. Chaieb (2005). Genomic DNA extraction method from pearl (Pennisetum glaucum) leaves. Afr. J. Biotechnol., 4: 862-866.

Table (S1). List of RAPD primers, their sequences and size range of the amplified fragments generated by randomly amplified polymorphic DNA (RAPD) markers for genetic analysis of in vitro probated and mother plants of Capparis spinosa var. deserti.

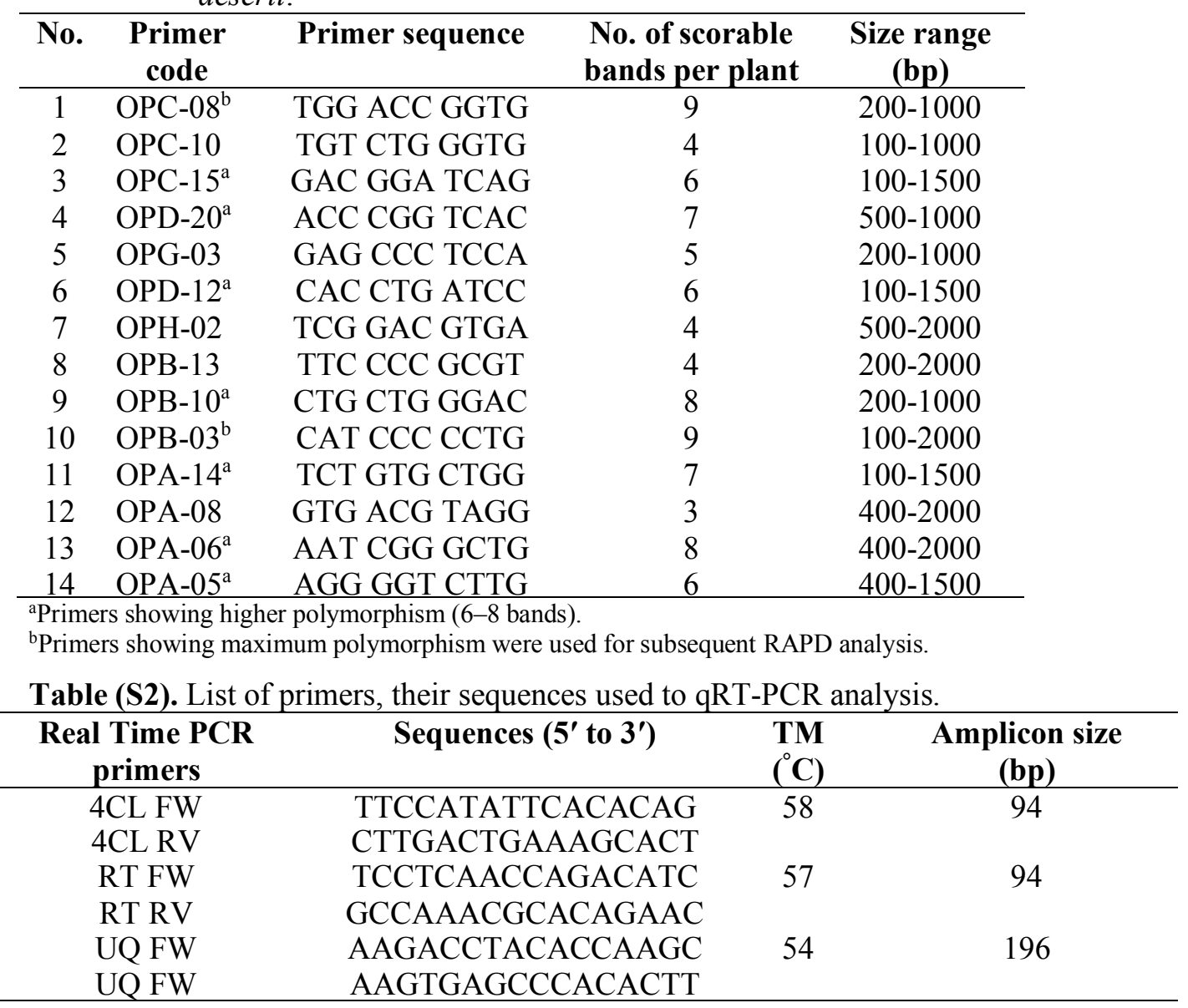




\section{الإكثار الدقيق والحفظ ودراسات جزيئية وكيميائية حيوية على نبات الكبار،

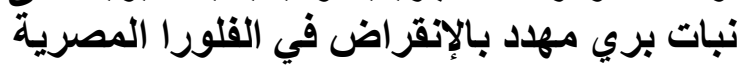

رضا السيد السبد أبو الفضل'، منال الصلاة على النبى أحمد'، تامر محفوظ عبد العظيم'، حمدي

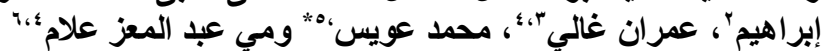

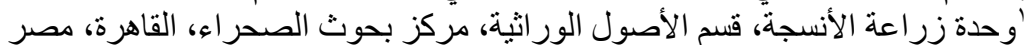

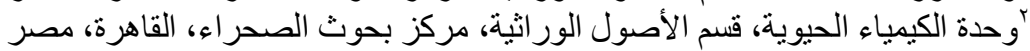

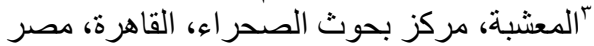

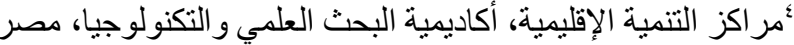

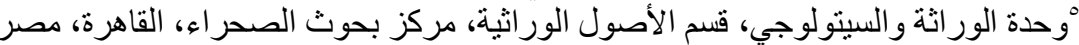

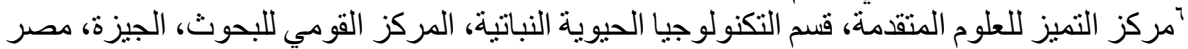

يعد نبات الكبار Capparis spinosa var. deserti أحد أهم النباتات الطبية الصالحة

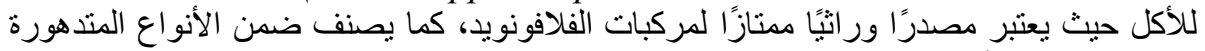

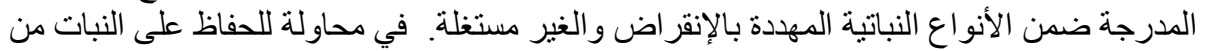

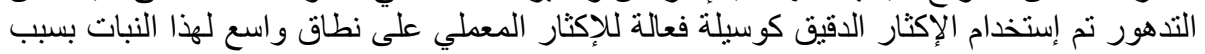

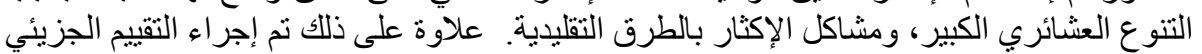

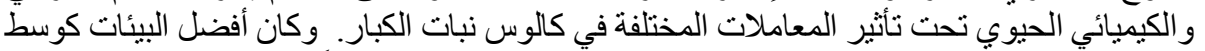

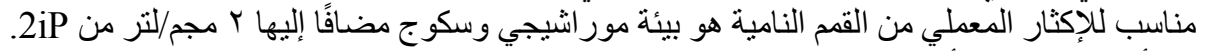

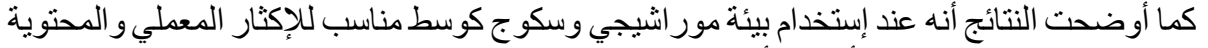

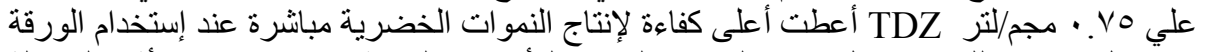

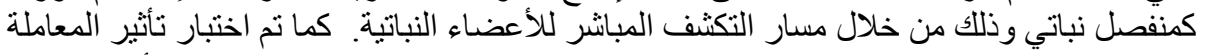

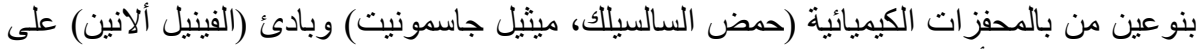

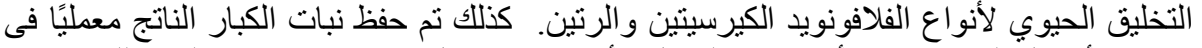

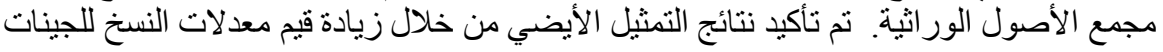
(4-coumaroyl CoA ligase and flavonol-3-O-glucoside L(rhamnosyltransferase

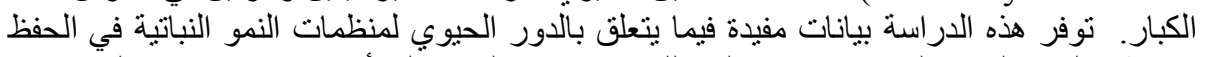

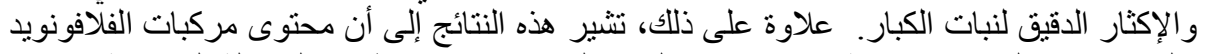

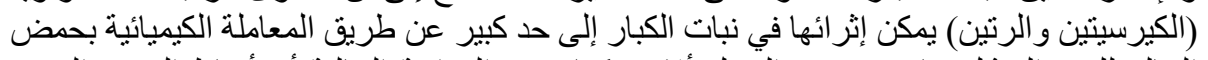

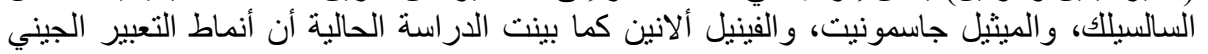
للجينات الخاصة بالتخليق الحيوي للكيرستين و الرتين يتم تنظيمها بو اسطة هذه المحفز ات الته 